\title{
The Origin and Significance of Medicaments According to Ben Sira (Sir 38:4-8)
}

\author{
ANDRZEJ PIWOWAR \\ Institute of Biblical Studies, John Paul II Catholic University of Lublin \\ andpiw@gazeta.pl \\ ORCID: 0000-0001-9316-1791
}

\begin{abstract}
In his reflection on doctors' work and the process of treatment (Sir 38:1-15), Ben Sira draws attention to the usage of medications (Sir 38:4-8). Many contemporary Jews were probably recalcitrant to use them as ancient medicine resorted to magic. Magic was also employed in the production of medications. The first part of the article synthetically presents the usage of medicines in ancient Israel on the basis of the Old Testament. Then a literary analysis and exegesis of Sir 38:4-8 is attempted. The present article takes into consideration the Greek version of this pericope, for it constitutes the canonical text of the Book of Sirach (the article nevertheless compares the Greek text to its Hebrew original). The pericope evinces a concentric structure (A - 38:4-5; B - 38:6; $\left.\mathrm{A}^{\prime}-38: 7-8\right)$. The verses that frame the pericope refer to medicines (vv. 4-5 are devoted to the justification of their use while vv. 7-8 mention the reasons they are used for). The central part (38:6), in turn, focuses on the origin of medical knowledge. Ben Sira strives to persuade his fellow Jews to use medications as they are not related to magic and pose no threat to believers. It is God who created them, and they come from him. The sage refers in his argumentation to what happened in Marah (cf. Exod 15:25) to justify the use of medicines and their natural origin. Medicaments help cure diseases and afflictions and they restore harmony of creation, disrupted by disease and suffering (38:8). Their divine provenance is also corroborated by the fact that knowledge of medicine and medications was given to people by God (38:6). Hence, people should worship God for this great gift. In Sir 38:4-8 Ben Sira performs a perfect synthesis of contemporary medicine developed by neighboring (pagan) peoples with Israel's faith (only God can cure a person but he does so through medications; medicine is thus a tool in his hands). The sage noticed the positive value and usefulness of medications but through referring to God and showing the divine provenance of medicine he dispelled any doubts the believers might have had concerning the use of medications to cure a disease.
\end{abstract}

KEYWORDS: The Wisdom of Sirach, Sir 38:4-8, medications, medicine, God-Doctor

$\mathrm{M}$ edical advances in the ancient civilizations of Egypt and Mesopotamia were accompanied by the development of pharmacology. Naturally, the term pharmacology is not deployed here in its contemporary sense - that is denoting a branch of science linking medicine, biology and chemistry - but as a science of plants and natural substances that can help restore health or alleviate pain and ailments. Medicine and pharmacology were closely connected from the start; each conditioned and supported the other. The relation between the two can also be 
noted in Ben Sira's reflection on the doctor and his work in Sir 38:1-15. The second part of this literary unit, that is Sir 38:4-8, is devoted to the origin and significance of medications. The present article offers a literary-exegetical analysis of the pericope. First, the use of medicaments in ancient Israel will be presented in a very synthetic way. Subsequently, the article will focus on Ben Sira's teachings on medicaments included in the fragment mentioned above (Sir 38:4-8).

\section{Medicaments and Their Use by the Israelites in the Times of the Old Testament}

From the contemporary point of view, pharmacology in its original form was in fact herbal medicine. ${ }^{1}$ It made use of natural qualities of primarily plants but also - with its development - of some mineral substances that helped cure wounds and alleviate pain and suffering in various kinds of diseases. Stabryła terms the first medicaments "remedies" or "medical measures." 2 To refer to רפא them, the Old Testament Hebrew made use of words formed from the root ("to heal"). The words include the following nouns: ("healing," "remedy"),

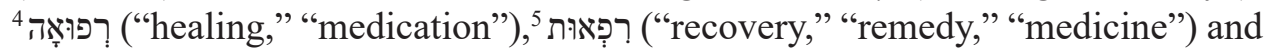
תִּרוּפָה ("healing," "medicine") ("What is interesting, the translation of the Old

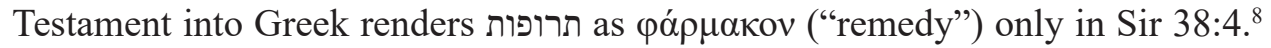
It may stem from the fact that the Greek word also meant "a magic remedy," "poison," "magic potion," or "spell."” It referred, then, to practices strictly prohibited

1 See S. Fasce, La lode del medico nel libro biblico del Siracide (Genova: ECIG 2009) 58-59.

2 See W.M. Stabryła, "Zdrowie i choroba w starożytnym Izraelu," Więcej szczęścia jest w dawaniu aniżeli w braniu. Księga Pamiatkowa dla Księdza Profesora Waldemara Chrostowskiego w 60. rocznice urodzin (ed. B. Strzałkowska) (Ad Multos Annos; Warszawa: Adam 2011) III, 1329.

$3 \quad$ It denotes "healing" in 2 Chr 21:18; 36:16; Prov 4:22; 6:15; Sir 43:22; Jer 8:15; 14:19; 33:6; Mal 3:20, and "remedy" in Prov 12:18; 13:17; 16:24; $29: 1$.

$4 \quad$ This is the word used most frequently in the Old Testament to denote medicaments (see Sir 3:28; Jer 30:13; 46:11; Ezek 30:21). Cf. L.A. Askin, Scribal Culture in Ben Sira (Sir 38:1-15; 41:1-15; 43:11-19; 44-50) (doctoral diss., Queen's College, Cambridge University 2016) https://www.repository.cam.ac.uk/handle/1810/255388 [access: 01.03.2020], 196; HALOT III, 1278.

$5 \quad$ See Sir 38:14; Prov 3:8. Cf. HALOT III, 1274.

6 See Ezek 47:12; Sir 38:4 (cf. Askin, Scribal Culture in Ben Sira, 196).

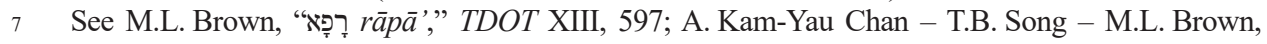
"רפא," NIDOTTE III, 1162.

8 See T. Muraoka, A Greek $\approx$ Hebrew / Aramaic Two-Way Index to the Septuagint (Louvain - Paris -

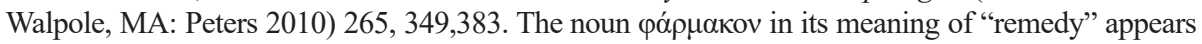
only in: Tob 2:10; 6:4,7; 11:8,11; Sir 6:16; 38:4.

9 See Z. Abramowiczówna (ed.), Stownik grecko-polski (Warszawa: Państwowe Wydawnictwo Naukowe 1958) IV, 496-497; O. Jurewicz (ed.), Stownik grecko-polski (Warszawa: Wydawnictwo Szkolne PWN 2001) II, 465; H.G. Liddell - R. Scott, A Greek-English Lexicon, 10 ed. (Oxford: 
by the Law (see Exod 22:17; Lev 20:6,27; Deut 18:9-14; Isa 47:9; Jer 27:9). It cannot be ruled out as well that the translators of the Old Testament into Greek understood the Hebrew word more in terms of "healing" (that is as an outcome of the treatment undertaken) rather than as "a remedy" (a means used in the pro-

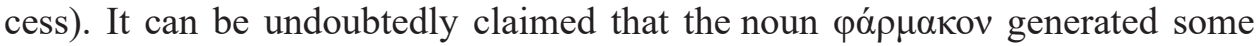
theological anxiety in them, which they preferred to avoid.

Even though in the pre-exile Israel medicine was not as developed and common as in the neighboring countries (especially Egypt and Mesopotamia) due religious reasons,${ }^{10}$ some medicaments were still deployed in certain diseases. ${ }^{11}$ Zakrzewska argues that in ancient Israel simple medicaments were in frequent use. In her view, this is corroborated by Wis 7:20; Isa 1:6 and Jer 8:22. ${ }^{12}$ Fasce confirms such a viewpoint, arguing that medicaments in Israel were even more widespread, as medicines known especially among the Romans and Greeks were produced in Palestine. ${ }^{13}$ It seems, however, that Fasce speaks of a later period, started by the Hellenistic period. In all likelihood, first medicaments were brought to Israel from Egypt. ${ }^{14}$

Speaking of medicaments, one needs to take into consideration the causes of pain or disease. In the case of external wounds, the causes are known, thus curing wounds seems easy. ${ }^{15}$ In the case of internal diseases, whose causes are unknown, treatment is much more difficult. ${ }^{16}$ To cure wounds, they were smeared with wine (see Luke 10:34), ${ }^{17}$ and various kinds of balm were applied to them (צָר "balm," in all likelihood it was pistachio tree resin; ${ }^{18}$ see Jer 8:22). 2 Kgs 20:7

Clarendon Press 1996) 1917; F. Montanari, Vocabolario della lingua greca, 2 ed. (Torino: Loescher Editore 2004) 2255; GELS, 711. See 2 Kgs 9:22; Wis 1:14; Mic 5:11; Nah 3:4.4.

$10 \quad$ See A. Piwowar, "Respect for the Doctor (Sir 38:1-3)," BibAn 10/1 (2020) 34.

11 "W związku z tym, że Izraelici nie wiedzieli zbyt wiele o rzeczywistych przyczynach chorób, używane środki medyczne ograniczały się w zasadzie do roślin i korzeni, które wcześniej okazały się skuteczne w leczeniu czy też łagodzeniu pewnych symptomów" (Stabryła, "Zdrowie i choroba w starożytnym Izraelu," 1329). Cf. M. Zakrzewska, "Choroba - zło dotykające człowieka," Biblia a medycyna (ed. B. Pawlaczyk) (Poznań: Księgarnia Świętego Wojciecha 2007) 21-22.

12 See Zakrzewska, "Choroba - zło dotykające człowieka," 24. Cf. M. Adinolfi, "Il medico in Sir 38,1-15," Anton 62 (1987) 178.

13 See Fasce, La lode del medico, 60.

14 See J.I. Packer - M.C. Tenney (ed.), Stownik tta Biblii (PSBibl; Warszawa: Vocatio 2007) 387.

15 See Zakrzewska, "Choroba - zło dotykające człowieka," 21.

16 See L. Boadt, Reading the Old Testament. An Introduction (New York: Paulist Press 1984) 248; Stabryła, "Zdrowie i choroba w starożytnym Izraelu," 1330; Zakrzewska, "Choroba - zło dotykające człowieka," 21.

17 "Winogrona cenione są jako pokarm dietetyczny, odznaczający się działaniem bakteriobójczym (zabijają pałeczkę okrężnicy i przecinkowca cholery)" (J. Pick, W świecie Biblii. Flora [Pelplin: Bernardinum 1998] 161). For the healing properties of oil see Pick, W świecie Biblii. Flora, 106.

18 See HALOT III, 1055; Stabryła, "Zdrowie i choroba w starożytnym Izraelu," 1330, n. 72. 
and Isa 38:1-8 describe King Hezekiah's disease and its treatment by applying a fig lump to the ulcer. ${ }^{19}$

In Song 4:12-14 there is a description of a garden, which enumerates many plants used in the ancient times as medicaments and cosmetics; in commenting upon the text, however, the majority of biblical scholars concentrate on their aro-

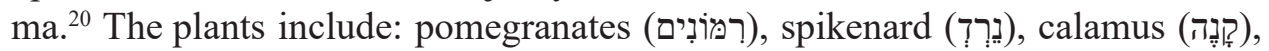

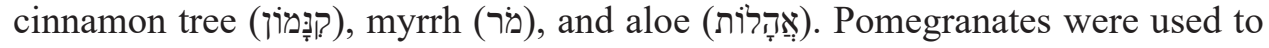
ease stomach trouble and to heal wounds, for they have anti-inflammatory properties. ${ }^{21}$ Spikenard helps prevent convulsion. ${ }^{22}$ Calamus was used in throat, mouth and nose diseases. ${ }^{23}$ It functioned also - like fig fruit ${ }^{24}$ - as a laxative. ${ }^{25}$ Cinnamon is to this day utilized in treating diabetes. ${ }^{26}$ The two final plants (myrrh and aloe) served to embalm and mummify dead bodies in ancient Egypt (cf. John 19:39). ${ }^{27}$ Aloe was also used as a laxative, ${ }^{28}$ while myrrh was used to produce ointments. The latter was also known as an expectorant and stimulant. ${ }^{29}$

An interesting fact on treating skin diseases may be found in the Book of Job. When Job fell sick (the Bible mentions leprosy, but according to Pawlaczyk this was diphtheria ${ }^{30}$ ), he sat on the ash (see Job 2:8). "In biblical times ash of burnt medical plants was used to treat skin diseases." 31

In the ancient times, medical qualities of olibanum, galbanum and mandragora were likewise noticed. The last one was treated as an aphrodisiac and a cure for infertility (see Gen 30:14-16). "In the ancient times, fresh mandragora

19 B. Pawlaczyk ("Kazuistyka medyczna," Biblia a medycyna [ed. B. Pawlaczyk] [Poznań: Księgarnia Świętego Wojciecha 2007] 127-128) believes that Hezekiah suffered from a furuncle. It may lead to sepsis, caused by Staphylococcus aureus. Pawlaczyk maintains at the same time that in the ancient times sapphires were treated as a remedy for furuncles and were applied to the inflamed skin.

20 See G. Barbiero, Cantico dei cantici (I Libri Biblici. Primo Testamento 24; Milano: Paoline 2004) 194-196; J.C. Exum, Song of Songs. A Commentary (OTL; Louisville, KY: Westminster John Knox 2005) 177-179; F.J. Gaiser, The Song of Songs. A Continental Commentary (Minneapolis, MN: Fortress 1994) 178-180; D. Garrett - P.R. House, Song of Songs/Lamentations (WBC 23B; Nashville, TN: Nelson 2004) 197-198; T. Longman III, Song of Songs (NICOT; Grand Rapids, MI - Cambridge: Eerdmans 2001) 157; M.H. Pope, Song of Songs. A New Translation with Introduction and Commentary (AB 7C; New York - London - Toronto: Doubleday 1977) 493-494; G. Ravasi, Il cantico dei cantici. Commento e attualizzazione (Testi e Commenti; Bologna: EDB 1992) 389-390. "The seeds were prescribed medicinally against tapeworm; while the rind served as an astringent, for skin problems and diarrhea" (I. Jacob - W. Jacob, "Flora," ABD II, 808).

22 See H. Langkammer, Księga Pieśni nad pieśniami (PST 8/4; Poznań: Pallottinum 2016) 87.

23 See Langkammer, Księga Pieśni nad pieśniami, 87.

24 See Pick, $W$ świecie Biblii. Flora, 46.

25 See Jacob - Jacob, "Flora," 813.

26 See Langkammer, Księga Pieśni nad pieśniami, 87.

27 See Langkammer, Księga Pieśni nad pieśniami, 87.

28 See Jacob - Jacob, "Flora," 805.

29 See Jacob - Jacob, "Flora," 812-813.

30 See Pawlaczyk, "Kazuistyka medyczna," 177-178.

31 Pawlaczyk, "Kazuistyka medyczna," 177, translation mine.

32 See Stabryła, "Zdrowie i choroba w starożytnym Izraelu," 1333. 
juice, dried root bark, leaves, salted extracts of roots and berries were all used as medicaments, while madragora wine served to alleviate pain, among others before surgical procedures." 33 Askin enumerates also dates, rue, and bee honey, alongside the plants and substances used in medicine and mentioned above (cf. Prov 16:24). ${ }^{34}$

The Book of Tobit corroborates that fish bile ( $\chi 0 \lambda \eta \dot{)})$ was used in the treatment of eye diseases (see 11:8). ${ }^{35}$ Tob 6:4 mentions also the healing properties of fish heart and liver. In Assyria, the bile of Kappū fish was mixed with butter and salt, and the mixture was applied in eye diseases. ${ }^{36}$

In the ancient times the healing properties of water from the Dead Sea were likewise known. Herod the Great used it as a remedy against psoriasis, which he suffered from. The bitumen found in the Dead Sea was used by the Greeks to produce ointment against furuncles. ${ }^{37}$ The bitumen's medical properties were corroborated by Flavius Josephus. ${ }^{38}$ Mud from the Dead Sea, in turn, yields positive results in various rheumatic conditions.

The Old Testament Jews made use of numerous substances of plant (cf. Ezek 47:12), animal and mineral origin to heal certain diseases and ailments. What is more, the Bible testifies also to the deployment of musicotherapy (see 1 Sam 16:15-17:23).$^{39}$ It is likely that the Israelites' knowledge about medicines came most frequently (perhaps almost exclusively) from their neighbors, especially from the Egyptians and Mesopotamians, as medicine in these two countries was way more developed than in Israel. It needs to be pointed out, however, that Jews evinced a lot of reservation towards medicaments and did not use them trustingly. This stemmed from their fidelity to the Law; they viewed doctors and medicine through the prism of their faith: since medicine to a large extent resorted to magic and since magic was forbidden by the Law, believing Jews radically rejected medicine. ${ }^{40}$ Magic practices were part and parcel of doc-

33 B. Szczepanowicz, Rośliny biblijne. Ziemia Święta (Kraków: Petrus 2014) 130-131, translation mine. Cf. Pawlaczyk, "Kazuistyka medyczna," 200.

34 See Askin, Scribal Culture in Ben Sira, 218.

35 See Pawlaczyk, "Kazuistyka medyczna," 230-231; G. Ravasi, "Malattia, Guarigione e medici nell'Antico Testamento," PSV 40 (1999) 21; J. Turkiel, "Septuaginta o lekarzu," Nauki humanistyczne i sozologia. Księga jubileuszowa dedykowana Księdzu Profesorowi zwyczajnemu doktorowi habilitowanemu Józefowi M. Dołędze (ed. J.W. Czartoszewski) (Warszawa: Wydawnictwo UKSW 2010) 565 .

36 See Stabryła, "Zdrowie i choroba w starożytnym Izraelu," 1330.

37 See Askin, Scribal Culture in Ben Sira, 218; Stabryła, "Zdrowie i choroba w starożytnym Izraelu," 1330-1331.

38 See J. Flawiusz, Wojna żydowska (Warszawa: Rytm 2016) IV, 481.

39 See Pawlaczyk, "Kazuistyka medyczna," 251-252.

40 See Askin, Scribal Culture in Ben Sira, 184; J. Giblet - P. Grelot, "Choroba-uleczenie," STB, 121; D. Lührmann, "Aber auch Arzt gib Raum (Sir 38,1-15)," WD 15 (1979) 55; Piwowar, "Respect for the Doctor (Sir 38:1-3)," 33-34; W.M. Stabryła, "NNajlepszego nawet lekarza czeka Gehenna'. 
tors' work: they resorted to magic in the process of healing and in preparing medicaments (cf. Enoch 8:3). ${ }^{41}$ This fact is confirmed by numerous testimonies and sources, both Egyptian and Mesopotamian.

Summing up, it may be concluded that believing Jews were faced with a serious dilemma when it came to the use of contemporary medicaments. On the one hand, they felt the need to use them in times of sickness and pain, as they could alleviate pain or contribute to complete healing. On the other hand, however, they were aware of the fact that the production of medicines may have been related to the use of magic practices, thus resorting to forces defying faith in the one and only God. Ben Sira offered Jews help in this difficult situation. In Sir 38:4-8 the sage shed new light on medicaments and their usage; doing so, he tried to dispel any doubts the Jews may have had with reference to the issue.

\section{Direct Context and Delimitation of Sir 38:4-8}

The context directly preceding the pericope analyzed in this article consists of a literary unit in which Ben Sira admonishes his disciples to respect the doctor (38:1-3). He justifies this admonition with reference to two premises: of a religious character (God created the physician [38:1b] and he is the source of healing [38:2a]) and a social one (rulers and other important personages in the society also benefit from doctors' services [38:2b and 38:3b] - the argument based on authority). The doctor is the dominant figure in the context preceding Sir 38:4-8.

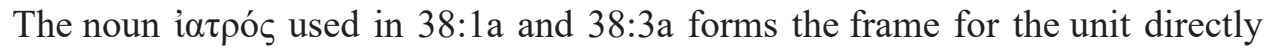
preceding Sir 38:4-8, marking at the same time the beginning of the fragment of Ben Sira's text analyzed in this article. ${ }^{42}$

Lekarz w starożytnym Izraelu," AK 160/1 (2013) 7-13. 8; idem, "Zdrowie i choroba w starożytnym Izraelu," 1327.1333; D.P. Sulmasy, "The Covenant within the Covenant: Doctors and Patients in Sir 38:1-15," LinQ 55 (1988) 14-24; Turkiel, "Septuaginta o lekarzu," 563-564; B. Zapff, "Sir 38,1-15 als Beispiel der Verknüpfung von Tradition und Innovation bei Jesus Sirach," Bib 92 (2011) 349-350.

41 "W miarę jak poznawano ludzki organizm, praktykowano nowe środki medyczne, a medycyna terapeutyczna i medycyna magiczna wzajemnie się uzupełniały, czego przejawem była współpraca lekarza i kapłana egzorcysty. Występowało wiele zaklęć magicznych związanych z medycyną, farmacją i wróżbiarstwem. Posługiwano się magią przy przygotowywaniu wywarów, naparów, okładów, maści, lewatyw" (Zakrzewska, "Choroba - zło dotykające człowieka," 18, emphasis in the original). Cf. N. Allan, "The Physician in Ancient Israel: His Status and Function," MediH 45 (2001) 389; W.H.C. Propp, Exodus 1-18. A New Translation with Introduction and Commentary (AB 2; New York - London - Toronto: Doubleday 1999) 580.

42 See Piwowar, "Respect for the Doctor (Sir 38:1-3)," 39. 
The beginning of the pericope devoted to medicaments is marked by the change of the subject (the protagonist). ${ }^{43}$ Beginning with 38:4, it is no longer the doctor, but God (кúpios). God appears at the beginning of each section of

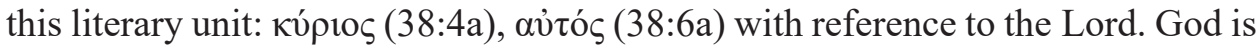
also the assumed subject of the form $\dot{\varepsilon} \theta \varepsilon \rho \alpha ́ \pi \varepsilon v \sigma \varepsilon v$ (literally, "he healed"). Almost all personal pronouns in the singular in this section refer to God (with the ex-

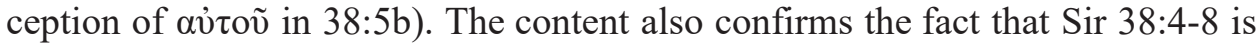
a coherent literary unit. The fragment concentrates on medicaments, their origin and the aim of their deployment. It needs to be emphasized that the Greek text of Sir 38:4-8 contains a clear frame. It is first formed by the noun "earth" ( $\dot{\varepsilon} \kappa \gamma \tilde{\eta} \varsigma-$ Sir 38:4a and غ̇ $\pi \grave{i} \pi \rho \circ \sigma \omega ́ \pi$ ov $\tau \tilde{\eta} \varsigma \gamma \tilde{\eta} \varsigma$ - Sir 38:8b). Furthermore, the beginning and ending of the pericope refer to creation: $38: 4 \mathrm{a}$ mentions the fact that the Lord

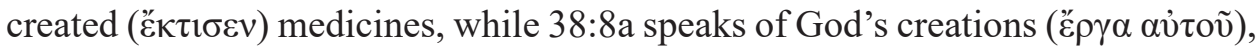
returning to the idea of creation - this time, the creation of the world.

The fact that the pericope analyzed here ends in Sir 38:8 is confirmed by the beginning of Sir 38:9.44 The verse begins with the vocative $\tau \varepsilon$ ḱvov ("child").

43 See W. Chrostowski, "Lekarz i jego posługa w świetle Biblii," CT 71/3 (2001) 64-66; F.J. Gaiser, “"The Sensible Will Not Despise Him': Healing Medicine, Human Wisdom and God (Sirach 38:1-15)," Healing in the Bible: Theological Insight for Christian Ministry (ed. F.J. Gaiser) (Grand Rapids, MI: Baker 2010) 124-125; A. Stöger, "Der Arzt nach Jesus Sirach (38,1-15)," ArztChr 11/1 (1965) 4-9. Not all scholars studying Sir 38:1-15 treat Sir 38:4 as the beginning of the pericope's new section (see V. Morla Asensio, Eclesiastico [El Mensaje del Antiguo Testamento 20; Salamanca: Sigueme 1992] 185-186; J.T. Nelis, "Sir 38,15," Von Kanaan bis Kerala [FS J.P.M. van der Ploeg] [ed. W.C. Delsman - J.T. Nelis - H.R.T.M. Peters] [AOAT 211; Kevelaer - New York: Butzon \& Becker Kevelaer 1982] 173; M.C. Palmisano, Siracide. Introduzione, traduzione e commento [NVBTA 34; Cinisello Balsamo: San Paolo 2016] 343; L. Schrader, "Beruf, Arbeit und Muße als Sinnerfüllung bei Jesus Sirach," Der Einzelne und seine Gemeinschaft bei Ben Sira [ed. R. EggerWenzel - I. Krammer] [BZAW 270; Berlin - New York: de Gruyter 1998] 135-136; J.G. Snaith, Ecclesiasticus or The Wisdom of Jesus Son of Sirach [CBC; Cambridge: Cambridge University Press 1974] 184; H. Stadelmann, Ben Sira als Schriftgelehrter. Eine Untersuchung zum Berufsbild des vor-makkabäischen Sōfêr unter Berücksichtigung seines Verhältnisses zu Priester-, Propheten- und Weisheitslehrertum [WUNT 2/6; Tübingen: Mohr \{Paul Siebeck\} 1980] 139; B.M. Zapff, Jesus Sirach 25 - 51 [NEchtBl. AT; Würzburg: Echter 2010] 253; idem, "Sir 38,1-15 als Beispiel" 358). Only a handful of exegetes support the division of Sir 38:1-8 into two sections: 38:1-3 and 38:4-8, proposed in this article (see Askin, Scribal Culture in Ben Sira, 207-208; Fasce, La lode del medico, 26-27.43; Gaiser, "The Sensible Will Not Despise Him," 124-125).

44 Biblical scholars working on Sir 38:1-15 are unanimous in believing that Sir 38:9 is the beginning of the second part of the pericope (see L. Alonso Schökel, Proverbios y Eclesiástico [Los Libros Sagrados 8/1; Madrid: Cristiandad 1968] 279-281; Askin, Scribal Culture in Ben Sira, 202.207-208; J. Corley, Sirach [New Collegeville Bible Commentary 21; Collegeville, MN: Liturgical Press 2013] 103-104; I. Cranz, "Advice for a Successful Doctor's Visit: King Asa Meets Ben Sira," CBQ 80/2 [2018] 237-238; Fasce, La lode del medico, 77; Gaiser, "The Sensible Will Not Despise Him," 124-125; S. Noorda, "Illness and Sin, Forgiving and Healing: The Connection of Medical Treatment and Religious Beliefs in Ben Sira 38,1-15," Studies in Hellenistic Religions [ed. M. Vermaseren] [EPROER 78; Leiden: Brill 1979] 222; Palmisano, Siracide, 344; G. Sauer, Jesus Sirach/Ben Sira [ATD. Apokryphen 1; Göttingen: Vandenhoeck \& Ruprecht 2000] 263; Schrader, "Beruf, Arbeit und Muße," 135-136; P.W. Skehan - A.A. Di Lella, The Wisdom of Ben Sira [AB 39; New York - Lon- 
In the Greek version of Ben Sira's text the word is a formula used to address his disciples to emphasize the solemnity and exceptional significance of his teachings. ${ }^{45}$ Moreover, the word frequently signals the beginning of new content (a new literary unit) in Ben Sira's book (see 2:1; 3:17; 4:1; 6:18; 16:24; 18:15; $21: 1 ; 37: 27 ; 38: 16 ; 40: 28)^{46}$ or functions as an element of a given pericope's structure (see $3: 12 ; 6: 23,32 ; 10: 28 ; 14: 11 ; 31: 22 ; 38: 9) .{ }^{47}$

The new literary unit starting with $38: 9$ is devoted to the attitude the sick one should adopt toward God. In accord with the initial evocation, the unit abounds in verbal forms expressed in the imperative form of the aorist in the second person singular (with the exception of $\pi \alpha \rho \alpha ́ \beta \lambda \varepsilon \pi \varepsilon$-imperativus praesentis in $38: 9 \mathrm{a}$ and ió $\sigma \varepsilon \tau \alpha \mathrm{l}$ - indicativus futuri in 38:9b) ${ }^{48}$ The deployment of so many imperative forms also makes Sir 38:9-11 a separate literary unit, coherent in terms of form and content, whose subject matter is the attitude of the sick person towards God.

On the basis of the arguments presented above, both relating to form and content, it needs to be concluded that Sir 38:4-8 constitutes a homogenous pericope, whose main subject matter are medicaments. ${ }^{49}$ It makes perfect sense in light of its direct context. The text is a continuation of Sir 38:1-3, as it justifies the usage of medicaments deployed by doctors in the treatment of diseases. Ben Sira calls on his disciples not to refrain from using medicaments prescribed by the doctors, just as they should not reject doctors' work as such. In Sir 38:4-8 he encourages a wisdom seeker to assume a proper attitude towards God in times of disease, for regaining health does not depend solely on the efforts and abilities of doctors but also - and primarily - on God's will, "for healing comes from the Most High" (38:2a). Medical procedures in themselves are insufficient to heal a person; God's help is essential, as - in accord with the traditional conviction expressed in the Old Testament - only the Lord can cure diseases and remove pain..$^{50}$

don - Toronto: Doubleday 1987] 441-442; E. Testa, "Le malattie e il medico secondo la Bibbia," RiBl 43 [1995] 260).

45 See A. Piwowar, "Wierność w czasie próby (Syr 2,1-6)," VV 11 (2007) 101.

46 See A. Minissale, Siracide. Le radici nella tradizione (LoB 1/17; Brescia: Queriniana 1988) 17.

47 See A. Piwowar, "Zdobycie mądrości według Syracha (Syr 6,18-37). Część I: Przyjęcie wychowania prowadzi do osiągnięcia mądrości (Syr 6,18-22)," BibAn 5/1 (2015) 113-114, 118; Schrader, "Beruf, Arbeit und Muße," 134.

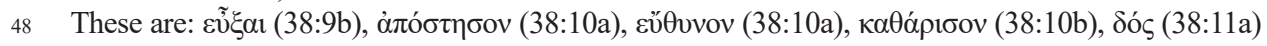
and $\lambda$ íravov (38:10b).

49 N. Peters (Das Buch Jesus Sirach oder Ecclesiasticus [EHAT 25; Münster: Aschendorff 1913] 311) posits that Sir 38:1-15 should be divided into six parts: I. 38:1-3; II. 38:4-6; III. 38:7-8; IV. 38:9-11; V. 38:12-14 and VI. 38:15.

$50 \quad$ See Piwowar, "Respect for the Doctor (Sir 38:1-3)," 33. 


\section{The Translation of the Greek Text of Sir 38:4-8}

My analysis in this article will be based on the translation of Sir 38:4-8 into Greek. ${ }^{51}$ This version has been chosen for analysis on account of the fact that it is considered canonical. The Hebrew text of the pericope is also known, ${ }^{52}$ and it will be referred to whenever there are some differences between the Hebrew and Greek versions. The Greek text reads as follows:

38:4 The Lord created remedies out of the earth, and a prudent man will not be appalled by them.

38:5 Was not water made sweet through wood so that its strength could be known?

38:6 And it was he that gave knowledge to human beings

in order to be glorified due to his marvelous deeds.

38:7 By them he cures and takes away his pain.

He who prepares unguents will make a mixture with them,

51 See J. Ziegler, Sapientia Iesu Filii Sirach, 2 ed. (SVTG 12/2; Göttingen: Vandenhoeck \& Ruprecht 1980) 299-300. Cf. A. Rahlfs (ed.), Septuaginta. Id est Vetus Testamentum graece iuxta LXX interpretes (Stuttgart: Deutsche Bibelgesellschaft 1979) II, 441-442.

52 See P.C. Beentjes, The Book of Ben Sira in Hebrew. A Text Edition of all Extant Hebrew Manuscripts and a Synopsis of all Parallel Hebrew Ben Sira Texts (VTSup 68; Leiden - New York - Köln: Brill 1997) 65-66; P. Boccaccio - G. Bernardi, Ecclesiasticus. Textus hebraeus secundum fragmenta reperta (Roma: PIB 1986) 25; The Book of Ben Sira. Text, Concordance and an Analysis of the Vocabulary (HDHL; Jerusalem: The Academy of the Hebrew Language and the Shrine of the Book 1973) 39; http://bensira.org/navigator.php?Manuscript=B\&PageNum=27 [access: 30.09.2018]. Cf. Askin, Scribal Culture in Ben Sira, 187; I. Lévi, The Hebrew Text of the Book of Ecclesiasticus (SSS; Leiden: Brill 1904) 44; Peters, Das Buch Jesus Sirach oder Ecclesiasticus, 311-312; idem, Der jüngst wiederaufgefundene hebräische Text des Buches Ecclesiasticus (Freiburg im Breisgau: Herdersche Verlagschandlung 1902) 156-157; Skehan - Di Lella, The Wisdom of Ben Sira, 439-440; R. Smend, Die Weisheit des Jesus Sirach erklärt (Berlin: Reimer 1906) 339-340; Zapff, Jesus Sirach 25 - 51, 254-255.

On the translation of the Hebrew text of Sir 38:4-8 see Adinolfi, "Il medico in Sir 38,1-15," 174; Askin, Scribal Culture in Ben Sira, 188; Lührmann, "Aber auch Arzt gib Raum (Sir 38,1-15)," 58; L. Mazzinghi, "«Poi fa” posto al Medico, perché ti è necessario» (Sir 38,1-15),” PSV 40 (1999) 66; C. Mopsik, La Sagesse de ben Sira (Les Dix Paroles; Lagrasse: Verdier 2003) 218-220; V. Morla, Los manuscritos hebreos de Ben Sira. Traducción y notas (Asociación Bíblica Española 59; Estella: Editorial Verbo Divino 2012) 219-220; Skehan - Di Lella, The Wisdom of Ben Sira, 438; http:// bensira.org/navigator.php?Manuscript $=\mathrm{B} \& \mathrm{PageNum}=27$ [access: 30.09.2018]. Cf. A. Minissale, Siracide (Ecclesiastico), 3 ed. (NVB 23; Cinisello Balsamo: San Paolo 2002) 178-179; Noorda, "Illness and Sin, Forgiving and Healing,"219, n. 9; Palmisano, Siracide, 343-345; Peters, Der jüngst wiederaufgefundene hebräische Text, 384; R. Smend, Die Weisheit des Jesus Sirach hebräisch und deutsch (Berlin: Reimer 1906) 65; J. Vella, "Eclesiastico," La Sagrada Escritura. Texto y comentario. Antiguo Testamento. V. Eclesiástico, Isaía, Jeremías, Ezequiel (ed. A.T. Fernández) (Madrid: Católica 1970) 156. 
38:8 and his works will never be finished,

and peace from him is upon the surface of the earth..$^{53}$

\section{The Exegetico-Theological Analysis of Sir 38:4-8}

The text of Sir 38:4-8 is divided into three parts and has a concentric structure: A. $-38: 4-5$; B. $-38: 6$; A' $-38: 7-8$. The verses forming the frame of the pericope

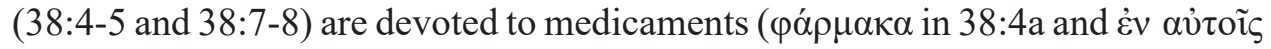

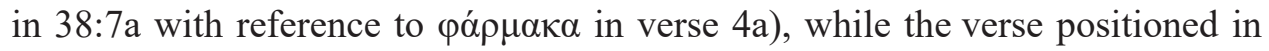
the center of the pericope (38:6) focuses on the origin and aim of medical knowledge. Sir 38:4-5 justifies the use of medicaments, while Sir 38:7-8 concentrates on the aim of their deployment. It needs to be emphasized that within a concentric structure most emphasis is put on the central element, which conveys the major message of the whole unit. The most crucial theologico-sapiential idea of Sir 38:4-8 is thus a conviction that knowledge of medicaments originates from God. God should be revered for sharing this knowledge with people, as the sick can be cured thanks to it.

Fasce also maintains that Sir 38:4-8 is divided into three parts. In her view, the first of these (38:4-5) praises the healing properties of natural medicines, the second part (38:6-7) extols the doctor's knowledge and skills, ${ }^{54}$ which are expressions of God's might, while the third one (38:8) can be treated as a continuation of previous content that once more commends the doctor's work. ${ }^{55}$ Such an understanding of the structure of Sir 38:4-8 needs to be rejected, as it posits

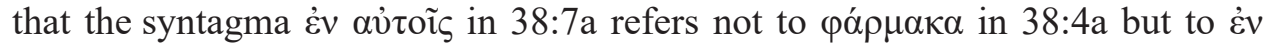

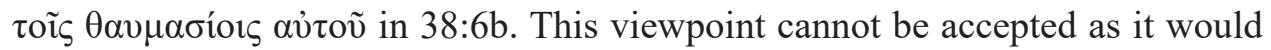
mean that the sick are cured by miracles and not by medicaments, while it is medicaments that are the main subject of the analyzed pericope. Granted, healing is a work of God and can be perceived as something extraordinary - as a miracle but Sir 38:4-8 expresses the conviction that God heals through medicaments pre-

53 On the translation of the Greek text of Sir 38:4-8 cf. Fasce, La lode del medico, 43.125; W. Kraus M. Karrer (ed.), Septuaginta Deutsch. Das griechische Alte Testament in deutscher Übersetzung (Stuttgart: Deutsche Bibelgesellschaft 2009) 1141-1142; Grecko-polski Stary Testament. Ksiegi greckie. Przeklad interlinearny z kodami gramatycznymi i indeksem form podstawowych (trans. M. Wojciechowski) (PSBibl; Warszawa: Vocatio 2008) 647; Palmisano, Siracide, 343-345; A. Pietersma - B.G. Wright (ed.), A New English Translation of the Septuagint. And the Other Greek Translations Traditionally Included under that Title (New York - Oxford: Oxford University Press 2007) 750; Septuaginta czyli Biblia Starego Testamentu wraz z ksieggami deuterokanonicznymi i apokryfami (trans. R. Popowski) (PSBibl; Warszawa: Vocatio 2013) 1245.

$54 \quad$ See Fasce, La lode del medico, 44.

55 See Fasce, La lode del medico, 46. 
scribed by the doctor and not through his own direct intervention for the sake of the sick to the exclusion of the physician. It needs to be noted as well that should

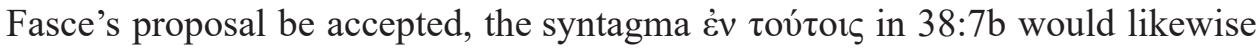
have to be applied to God's miracles and not to medicaments. This final argument is sufficient to reject the structure of Sir 38:4-8 proposed by Fasce, as it suggests that healing ointments may be created out of miracles performed by God.

\subsection{Justification of the Use of Medicaments (Sir 38:4-5)}

The sage gets straight to the point and gives the major argument in favor of using medicaments: they are to be used for they were created by God (38:4a: kópios

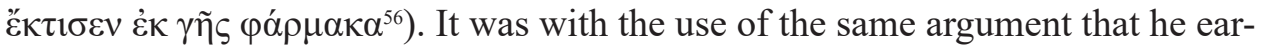
lier justified showing respect to the doctor (see 38:1b; the same idea is reiterated in 38:12a). ${ }^{57}$ A person who is sick and suffering should not fear using remedies, as they do not come from demonic forces; neither have they been produced via magic procedures, but they were created by God. ${ }^{58}$ Hence, they are good and can be used..$^{59}$

In accord with Gen 1-2, Ben Sira concludes that God created everything. He also notices the purposefulness and necessity of creations (see Sir 39:21). God had known all of his creations even before they were created (see 23:20). Everything, without an exception, was created "in common" (see 18:1). God's first creation is wisdom, which was brought into being prior to other entities (see 1:4; 24:9; cf. 1:9; 24:8). God also created his great glory (see 44:2). Out of God's creations, man is worthy of a particular attention, having been created out of earth (see 17:1;33:10). Out of all men, nobody was created greater than Enoch (see 49:14). People should not abhor hard work and farming, for these too were created by God (see 7:15). Pride and haughtiness are not for people (see 10:18), but wine was created by God to make them merry (see 31:27). The worst of all creations is a wicked eye (see 31:13). The intentionality of all creations men-

56 Fasce (La lode del medico, 43-44) argues that the noun кúplos emphasizes the subject of the sentence on account of its position at the very beginning of Sir 38:4a. In her view, this makes the verb $\kappa \tau i \zeta \omega$ assume a particular significance. It is difficult to assess this viewpoint univocally as the order of subject and verb in a sentence is not rigidly fixed in Greek and can be changed (see A. Piwowar, Sktadnia języka greckiego Nowego Testamentu, 2 ed. [MPWB 13; Lublin: Wydawnictwo KUL 2017] § 453).

57 See Piwowar, "Respect for the Doctor (Sir 38:1-3)," 43-44.

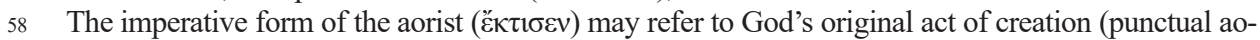
rist) but it may also be treated as gnomic aorist. In accord with the latter interpretation, it should be translated in the present tense ("creates"), as it expresses a universal activity which is continued. Such

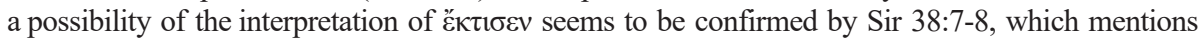
God's unceasing creative activity (see section 4.3 of the present article).

$59 \quad$ See Fasce, La lode del medico, 62. 
tioned above is emphasized by the sage also by stating that good was created for good people while evil for the sinners (see 39:25). Winds, fire, hail, famine, death, blood, strife, sword, misfortune, persecution and a lash as punishment for sin were created for the godless (see 39:28-29; 40:10), while anguish - for everybody (see 40:1). Out of his own will God created also the doctor and medicines used by the physician in his work (see 38:1,4,12). ${ }^{60}$ Many exegetes see Sir 38:4a as an allusion to Gen 1:12a. ${ }^{61}$ Zapff stresses the fact that Ben Sira modified the content of the verse from the Book of Genesis: in Gen God orders the earth to yield plants, while the sage attributes their creation to God himself. ${ }^{62}$ What is more, Zapff sees Sir 38:4a also as a reference to Gen 2:9. ${ }^{63}$

The noun $\varphi \alpha ́ \rho \alpha \mu \kappa o v ~(" r e m e d y " 64)$ appears in the Greek version of Ben Sira's text only once more apart from 38:4a ${ }^{65}$ In Sir 6:16 the sage calls a loyal friend life's medicine ( $\varphi \alpha ́ \rho \mu \alpha \kappa o v ~ \zeta \omega \tilde{\eta} \varsigma) .{ }^{66}$ The noun "medicine" is used here metaphorically and with a positive meaning. It denotes - in a general and enigmatic way something good, analogous to a friend, who is presented as invaluable in the Old Testament (see Sir 6:14). Фápнакоv is not perceived by the sage as related to magic and as posing a threat to a believer; on the contrary, it is something good. Medicaments were created by God, thus they are good and not to be feared. They manifest God's might and glory ${ }^{67}$ In the Greek version of Ben Sira's text the noun applies only to medicaments but in other books of LXX it may denote magic practices or sorcery. It was clearly because of the latter meaning that believing Jews approached medicaments with reasonable caution (see section 1). ${ }^{68}$

Ben Sira claims that God created medicaments out of earth ( $\dot{\varepsilon} \kappa \gamma \tilde{\eta} \varsigma)$. In this way, he emphasizes their relation to the act of creation. ${ }^{69}$ They do not stem from spiritual spheres and are not an outcome of the activity of magic forces (demons or pagan deities). They come from the same earth that the man was created out

60 See Piwowar, "Respect for the Doctor (Sir 38:1-3)," 43-44.

61 See Askin, Scribal Culture in Ben Sira, 196-197; Cranz, "Advice for a Successful Doctor's Visit," 243; Lührmann, "Aber auch Arzt gib Raum (Sir 38,1-15)," 61; Zapff, "Sir 38,1-15 als Beispiel," 354.

62 See Zapff, "Sir 38,1-15 als Beispiel," 360-361.

63 See Zapff, Jesus Sirach 25-51, 254.

64 "Here Sirach's grandson, in the use of the word $\varphi \alpha ́ \rho \mu \alpha \kappa \alpha$, embraces the medicaments current in Alexandria along with Jewish folk remedies, including magic, which so fascinated the non-Jewish populace" (Allan, "The Physician in Ancient Israel: His Status and Function," 389-390).

65 "L'accento posto dal Siracide sui pharmaka, cioè sui rimedi naturali, corrisponde allo stato delle conoscenze disponibili all'epoca in cui l'autore scrive e il nipote traduce. In sintonia col Siracide, un passo del Libro dei Giubilei, risalente all'ultimo quarto del II sec. a.C., presenta le erbe salutari entro il quadro della creazione divina, riferendo la tradizione secondo la quale Noè avrebbe composto un libro di farmaceutica" (Fasce, La lode del medico, 58). Cf. Księga Jubileuszów 10,10-14.

66 See J.J. Pudełko, Wierny przyjaciel lekarstwem życia (Syr 6,16). Koncepcja przyjaźni w Księdze Syracydesa (RSBibl 28; Warszawa: Vocatio 2007) 87-89.

67 See Fasce, La lode del medico, 43.

68 Cf. Allan, "The Physician in Ancient Israel: His Status and Function," 389.

69 See Adinolfi, "Il medico in Sir 38,1-15," 177. 
of, so from the material point of view they do not differ in their essence from human beings.

Since medicaments were created by God, they must be good and beneficial; they should not be rejected or despised. Ben Sira expresses this idea in a straightforward way in the second stich of the analyzed pericope (38:4b): "a prudent man

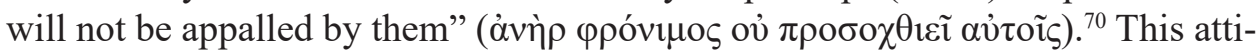
tude is a consequence of Sir 38:4a. ${ }^{71}$ On the basis of Sir 38:4b, Fasce concludes that the sage is conscious of the novelty of what he is teaching and he addresses his ideas to people possessing critical abilities. ${ }^{72}$ The adjective $\varphi \rho o ́ v \imath \mu o \zeta$ ("prudent," "reasonable," "sensible," "wise") always refers to a person in the Greek version of Sir, never to an object or a thing. A prudent man accepts chastisement in silence (see 20:1). He pleases the mighty (see 20:27). His words are sought after in the assembly and are heeded in one's heart (see 21:17). Education/formation $(\pi \alpha 1 \delta \varepsilon i \alpha)$ is like a valuable ornament for him (see 21:21). Were a prudent man to eavesdrop at the door, it would smear his honor (see 21:24). He is in control of his words (see 21:25). A prudent daughter will get married, but one who brings shame upon her father will be a source of anguish for him (see 22:4). Even though the Greek text of Ben Sira's work does not state that explicitly, it may be assumed that a prudent (reasonable) person shows features of a wise person and may be considered as such. This is corroborated by the connection between their activities and those of a sage (ó бopós) in 20:27 and the role of education (formation) in their life (see 21:21; cf. 21:24). As Ben Sira puts it in Sir 38:4b, a man shows his wisdom also by not rejecting medicines (the pronoun $\alpha$ vo $\tau$ ĩ $\varsigma$ refers to

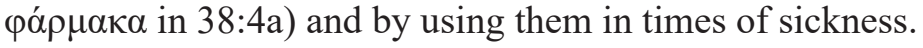

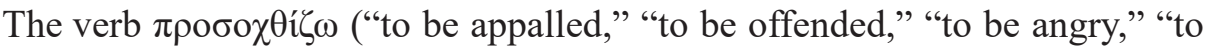
bear a grudge against someone") appears three more times in the Greek text of Sirach apart from 38:4b. In 6:25 the sage encourages those who seek wisdom to yield to it and not chafe at its constraints. ${ }^{73}$ In 25:2 he expresses his indignation at three types of people: a haughty pauper, a wealthy liar, and a lascivious old man who lacks intelligence. In 50:25 in turn he gives voice to his anger at the inhabitants of the mountains of Samaria and the Philistines. The verb analyzed here thus expresses a negative attitude towards people or things. It signifies lack of acceptance: one's isolation from and rejection of something or someone. In 38:4b the sage calls upon his disciple/reader not to adopt such a stance towards medicines. He should accept them in the same way as a wisdom seeker accepts the bonds of wisdom. The imperative form of the present tense preceded by ne-

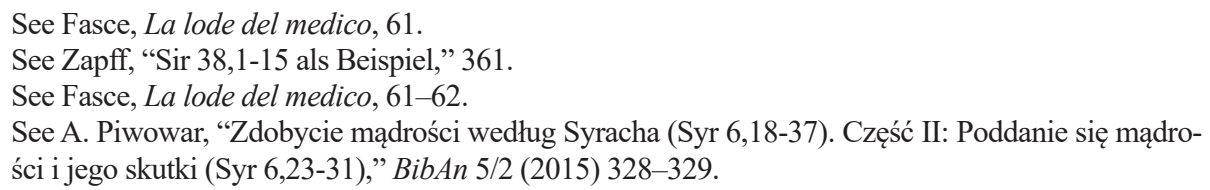


gation (oủ $\pi \rho \circ \sigma o \chi \theta 1 \varepsilon \tilde{\text { }}$ ) does not denote a single act but a constant attitude that should be adopted, continued and always repeated in times of sickness. The syn-

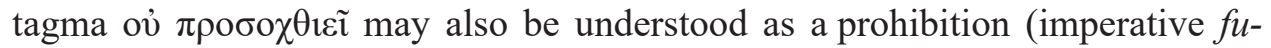
turum $^{74}$ ): "do not be appalled."

The first argument justifying the use of medicines in times of sickness and pain is of a theological character. It refers to the act of creation, ${ }^{75}$ during which God brought to being various natural substances that may help a sick person regain health (38:4a) ${ }^{76}$ The second precept that Ben Sira refers to is of a sapiential character, even if it is based on the first argument and alludes to it ( $\kappa \alpha i$ in 38:4b may be treated as kaí explicativum ${ }^{77}$ ). A prudent man does not view medicaments as products of forces opposing God and, as a result, he does not despise or reject them. His wisdom manifests itself in proper judgment, an understanding of their origin, and use of medicines during illness. Medicines, like the doctor himself (Sir 38:1-3), are not against God, the only Doctor who can bring back health. What is more, medicaments are an expression of God's care for the sick and a gift to them. ${ }^{78}$ They need to be perceived in light of faith in the Creator of all that exists, and their natural power - not magic or demonic - needto be acknowledged.

The message of the Hebrew text of Sir 38:4 is in essence the same as of its translation into Greek. Even though slight differences between the two versions may be discerned, they do not have significant impact on the message of the verse. Manuscript B contains two different wordings of the ending of the first stich of 38:4. The main text (B ${ }^{\text {text }}$ ) reads "God brought forth remedies out of the earth"), while the margin (B $\left.{ }^{\text {marg }}\right)$ suggests that the final two words be read as ("he created healing herbs"79). Comparing the original

74 See Piwowar, Składnia języka greckiego Nowego Testamentu, § 358.

75 Zapff("Sir 38,1-15 als Beispiel," 360; Jesus Sirach 25-51, 254) sees it as a reflection of the influence of Stoic philosophy on Ben Sira's teachings.

76 See Stöger, "Der Arzt nach Jesus Sirach (38,1-15)," 7.

77 See F. Blass - A. Debrunner, Grammatica del Greco del Nuovo Testamento, 2 ed. (ISB.S 2; Brescia: Paideia 1997) § 442.6; GELS, 354-355.

78 See Cranz, "Advice for a Successful Doctor’s Visit,” 243; Mazzinghi, “«Poi fa” posto al Medico, perché ti è necessario» (Sir 38,1-15)," 69; Zapff, "Sir 38,1-15 als Beispiel," 361.

79 See $D H C$ IV, 167; http://bensira.org/navigator.php?Manuscript=B\&PageNum=27 [access: 30.09.2018]; Mopsik, La Sagesse de ben Sira, 218. Morla (Los manuscritos hebreos de Ben Sira, 219, n. 8) believes that the noun שמים has the same meaning ath words in turn have the same meaning as תרופות. Cf. DHC IV, 167. It needs to be pointed out, however, that שמים written in this way (with the initial sîn) appears only in Sir 38:4. In Sir 49:1a סמים appears (with the intial sămek) in the sense of "aromatic incense" (see Vella, "Eclesiastico," 156). The noun appears in the same form in Exod 25:6; 30:7,34; 31:11; 35:8,15; Lev 4:7; 16:12; 2 Chr 2:3 and Sir 49:1 (see $D B H E, 532 ;$ HALOT II, 759). Yastrow states that later the Hebrew noun oo signified "remedy" or "poison" (see M. Yastrow [ed.], A Dictionary of the Targumim, the Talmud Babli and Yerushalmi, and the Midrashic Literature with an Index of Scriptural Quotations [New York: The Judaica Press 1996] II, 998). 
text with its Greek version, it may be claimed that the translation conducted by Ben Sira's grandson seems to take into consideration both variants of the first ברא (B ${ }^{\text {marg }}$ ), while $\varphi \alpha ́ p \mu \alpha \kappa \alpha$ is rather a literal translation of תרופות, and not of שמים. It needs emphasizing that both wordings of the Hebrew text of Sir 38:4a seem to reflect the state of original pharmacology (herbal medicine) more than the Greek version of the stich. They accentuate more the natural provenance of medicines, which are called in $\mathrm{B}^{\text {marg }}$ healing herbs. ${ }^{80}$

The translation of the second stich of Sir 38:4 into Greek does not significantly depart from its original version as well (וגבר מבין אל ימאס בם). Some nuances of difference may nevertheless be noted here. Firstly, the original version of $38: 4 b$ emphasizes the fact that the text is addressed to a young and strong person (גבר) who is in his prime: he does not fall sick and has not aged yet. It is to him that the sage directs his admonition not to reject (אל ימאס) medicaments. The Hebrew text signals a more decisive and negative approach towards medicines (rejection) than the Greek text does (indignation, aversion). The difference in attitude may stem from the fact that in Hellenized Alexandria medicaments were more common and accessible (and, by inference, accepted) than in Israel. They did not generate as much fear as they did among the Jews in Palestine.

In Sir 38:5 the sage presents another argument in favor of using medicines, which also indicates that the healing power of medicines comes from nature. The argument may be called historico-redemptive or scriptural as it refers to the Holy Scripture ${ }^{81}$ (in Lührmann's view the argument may be noticed already in Sir 38:4 ${ }^{82}$. Ben Sira alludes to an event that occurred as the Israelites were wandering through the desert to the Promised Land and they reached Marah. The water there was bitter, so the Israelites could not drink it and complained about Moses. He called upon God for help. God told him to throw a piece of wood into the water. When Moses did so, the water became potable. In this way God saved his people from death (Exod 15:23-25). ${ }^{83}$ Alluding to this event in Sir 38:5a, the sage asks a rhetorical question introduced with oủ

$80 \quad$ See Zapff, "Sir 38,1-15 als Beispiel," 354-355.

$81 \quad$ See Schrader, "Beruf, Arbeit und Muße," 138-139.

82 See Lührmann, "Aber auch Arzt gib Raum (Sir 38,1-15)," 61.

83 See Adinolfi, "Il medico in Sir 38,1-15," 178; Allan, "The Physician in Ancient Israel: His Status and Function," 390; Alonso Schökel, Proverbios y Eclesiástico, 280; J.L. Crenshaw, "The Book of Sirach. Introduction, Commentary, and Reflection," The New Interpreter's Bible (ed. L.E. Keck) (Nashville, TN: Abingdon Press 1997) V, 807; H. Duesberg, "Le médecin, un sage (Ecclésiastique 38,1-15)," BVC 38 (1961) 47; Fasce, La lode del medico, 48-49; Gaiser, "The Sensible Will Not Despise Him," 118-119; Mazzinghi, "«Poi fa' posto al Medico, perché ti è necessario» (Sir 38,1-15)," 70; T. Middendorp, Die Stellung Jesu Ben Siras zwischen Judentum und Hellenismus (Leiden: Brill 1973) 59; Mopsik, La Sagesse de ben Sira, 219, n. 1; Palmisano, Siracide, 343; Skehan - Di Lella, The Wisdom of Ben Sira, 442; Snaith, Ecclesiasticus, 185; Stöger, "Der Arzt nach Jesus Sirach (38,1-15)," 7; Sulmasy, "The Covenant within the Covenant," 20. 
(“did/did not?"). ${ }^{84} \mathrm{He}$ does not expect an answer - it is obvious and unquestionable - but he emphasizes the statement through making it into a question. Ben Sira refers to the event described in Exod 15:23-25 in a very synthetic way. He does not describe it in detail for it was known to all of his listeners/readers. ${ }^{85}$ He concentrates exclusively on the outcome of Moses' deed, thanks to which undrinkable water became safe to drink ${ }^{86}$ Sir $38: 5$ a constitutes a univocal and clear reference only to Exod 15:25, ${ }^{87}$ as these two verses only contain three crucial words, namely the nouns $\xi u ́ \lambda o v$ ("tree," "wood") and v̋ $\delta \omega \rho$ ("water") and

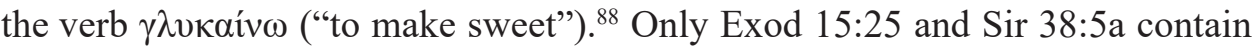

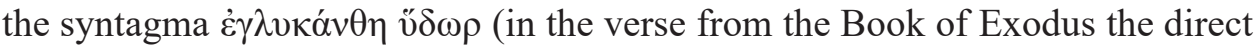

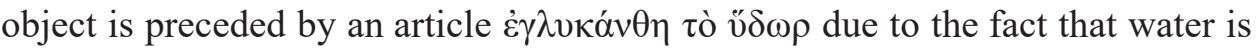
mentioned in the preceding verse 22 ; the article functions then as an anaphora ${ }^{89}$ ). Askin calls Ben Sira's text a quote, noticing at the same time that Sir 38:5a is the first medical interpretation of Exod 15:25-26. ${ }^{90}$ Both texts seem to accentuate more the beneficial capabilities of nature than the miraculousness of what happened in Marah. ${ }^{91}$ This aspect is emphasized particularly by Sir 38:5a, as it directly mentions the role of wood in making the water drinkable. The syntagma $\dot{\alpha} \pi$ ò $\xi u ́ \lambda o v$ may be interpreted in two different ways, depending on the role and function of the preposition àmó. First of all, it may refer to wood as a cause of, a reason for or a means through which an activity is performed ("on account

84 See Fasce, La lode del medico, 47; Piwowar, Sktadnia języka greckiego Nowego Testamentu, $§ 460$ b.

85 See Fasce, La lode del medico, 50-51.56.

86 See Fasce, La lode del medico, 49.

87 See Askin, Scribal Culture in Ben Sira, 198; Cranz, "Advice for a Successful Doctor's Visit," 243; Fasce, La lode del medico, 48; Lührmann, "Aber auch Arzt gib Raum (Sir 38,1-15)," 62; Noorda, "Illness and Sin, Forgiving and Healing," 219, n. 13; Zapff, "Sir 38,1-15 als Beispiel," 361; idem, Jesus Sirach 25-51, 254.

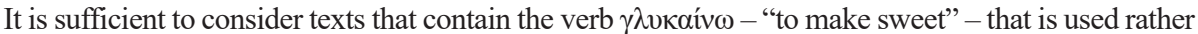
rarely in LXX (see Exod 15:25; Job 20:12; 21:33; Ps 54:15; Sir 12:16; 27:23; 38:5; 40:18,30; 47:9; $49: 1 ; 50: 18$ ). In the Greek version of Sir it appears seven more times apart from 38:5a (see 12:16; 27:23; 40:18,30; 47:9; 49:1 and 50:18). It is always used in a metaphoric way. Most often it expresses an amiable attitude that causes a lot of joy (see 40:18 and 49:1), even if it is not always sincere (see $12: 16 ; 27: 23 ; 40: 30)$. Twice the verb is used with reference to a musical melody pleasing to the ear (see 47:9 and 50:18).

89 See Piwowar, Składnia języka greckiego Nowego Testamentu, § 91.

90 See Askin, Scribal Culture in Ben Sira, 198-199.

91 'Z gramatycznej sekwencji zdania wynika, iż Bóg zakłada, że Mojżesz wie co zrobić. Działanie Boga opiera się więc na ludzkiej wiedzy i w praktyce oznacza, że nie ma tu mowy o cudzie, lecz właściwym wykorzystaniu praw natury” (J. Lemański, Księga Wyjścia [NKB.ST 2; Częstochowa: Edycja Świętego Pawła 2009] 350). "Ben Sira broke with the traditional understanding of this event as a Deus ex machina miracle. He interprets this twig as a pharmaceutical agent, which already had the power to "cure' the waters inhering in its substance" (Sulmasy, "The Covenant within the Covenant," 20). Cf. Crenshaw, "The Book of Sirach," 807; Gaiser, "The Sensible Will Not Despise Him," 118-119; Mopsik, La Sagesse de ben Sira, 219; Stöger, "Der Arzt nach Jesus Sirach (38,1-15)," 7; Zapff, "Sir 38,1-15 als Beispiel," 361; idem, Jesus Sirach 25-51 254. 
of," "with the help of," "thanks to"). Secondly, when combined with the passive form ( $\dot{\varepsilon} \gamma \lambda v \kappa \alpha ́ v \theta \eta)$, it may be treated as pointing to a thing (in the case of the stich under analysis here) which performed the activity expressed in the passive voice ("it was made sweet by wood"). Typically, preposition vं such a case, but it may also be substituted with $\dot{\alpha} \pi$ ó. ${ }^{92}$ It needs to be emphasized, however, that in the Greek version of Sir the latter preposition never indicates the major agent of an activity expressed in the passive voice. Such a function is

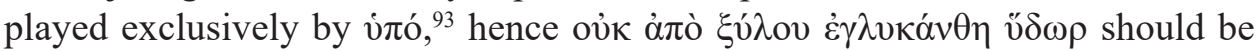
translated as: "Was not the water made sweet with the help of/through wood?" What is more, if wood was the subject of $\dot{\varepsilon} \gamma \lambda v \kappa o ́ v \theta \eta$ in Sir 38:5a, this would ruin the coherency of the literary unit of Sir 38:4-8, in which God is the protagonist. As a result of the interpretation of the preposition $\dot{\alpha} \pi$ ó given above, $\dot{\varepsilon} \gamma \lambda v \kappa \alpha ́ v \theta \eta$ is treated as passivum theologicum, which means that God made water drinkable. ${ }^{94}$ In the Greek text of Exod 15:25 as well, the form $\dot{\varepsilon} \gamma \lambda v \kappa \alpha$ v $\theta \eta$, with no agent mentioned, clearly suggests that it is passivum theologicum. The same idea is expressed in Sir 38:5a. The verse, nevertheless, emphasizes the role of wood ( $\dot{\alpha} \pi$ ò $\xi u ́ \lambda o v)$ in making water potable. God made use of a twig to make water safe to drink. Ben Sira's interpretation of the Marah event emphasizes the fact that wood is an intermediary agent. In this way, he referred to the theological truth of the Old Testament that only God may heal, while at the same time expressing a conviction that God can do so with the use of various objects that were endowed in the act of creation with a hidden power of curing diseases and alleviating pain. ${ }^{95}$

Ben Sira referred to the event depicted in Exod 15:25 with a view to proving the thesis expressed in 38:4a that there exist natural medicines and that plants and natural substances created by God have a healing potential (cf. 2 Kgs 2:21-22; Ezek 47:8-9,1196). The healing properties of medicaments are not an outcome of magic procedures but of powers inherent in some creations since their inception. ${ }^{97}$ For this reason, one should not be wary of medicaments, for their healing properties come from God, ${ }^{98}$ who created them and endowed them from the very be-

92 See Piwowar, Skladnia języka greckiego Nowego Testamentu, § 295.

93 See Sir 3:5,16; 13:21; 14:27; 30:19; 45:1; 46:13; 48:12 and 50:2.

94 See Fasce, La lode del medico, 49.

95 See Fasce, La lode del medico, 49.

96 These texts also mention purification of water. It needs to be emphasized that Sir 38:5 does not refer to them, as in 2 Kgs 2:21-22 the verb ióoual ("to heal") appears, and what is more Elijah

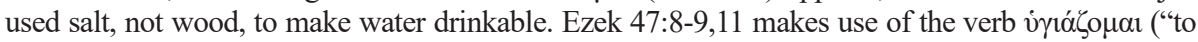
treat," "to heal"), and water is "healed" by water flowing from the temple (cf. Adinolfi, "Il medico in Sir 38,1-15," 178, n. 16; Alonso Schökel, Proverbios y Eclesiástico, 280).

97 See Lührmann, "Aber auch Arzt gib Raum (Sir 38,1-15)," 62.

98 See Mopsik, La Sagesse de ben Sira, 219, n. 2. 
ginning with exceptional medical properties. ${ }^{99}$ Sir $38: 5$ a then offers a theological justification of natural medicine, especially herbal medicine.

The second stich of Sir 38:5 offers a justification of the event described in the first part of the verse. ${ }^{100}$ Water became sweet thanks to wood so that its

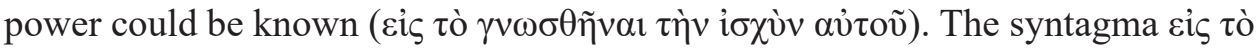
$\gamma \nu \omega \sigma \theta \tilde{\eta} v \alpha l^{101}$ may be interpreted in two ways. It may express a subordinate clause of purpose ("so that its power will be known") ${ }^{102}$ or a subordinate clause of result ("so its power became known"). ${ }^{103}$ Fasce supports the first interpretation. ${ }^{104}$ Both make perfect sense in the context of Sir 38:5 and it is difficult to decide univocally which is correct. If it is a clause of purpose, it would express God's intention to familiarize the Jews with the beneficial power of wood. As a clause of result, it would accentuate the final outcome of the Marah event, stressing the fact that the Jews learnt about and accepted natural healing properties of wood. When it

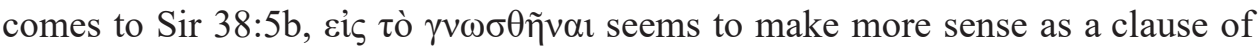
result and not of purpose, since Sir 38:6a mentions knowledge granted to people by God. It thus seems to emphasize the result - and not the purpose - of cognition with reference to medical knowledge. A decisive conclusion whether the syntagma analyzed here is a clause of purpose or that of result is not of major importance; what is more significant is the message conveyed by Sir 38:5: some plants have positive qualities and powers that help cure disease and save people from death.

The interpretation of the personal pronoun in the genitive case ( $\alpha$ v่ oṽ) also poses some difficulty. It may refer both to wood (if we assume that it is in

99 " $[. .$.$] l'ordine naturale, tuttavia, non è immanente alla natura stessa come nel mondo greco, ma è stato$ creato da Dio, così come l'episodio dell'Esodo conferma" (Mazzinghi, "«Poi fa' posto al Medico, perché ti è necessario» [Sir 38,1-15]," 70). Cf. J. Marböck, Weisheit im Wandel. Untersuchungen zur Weisheitstheologie bei Ben Sira (BZAW 272; Berlin - New York: de Gruyter 1999) 157; Sulmasy, "The Covenant within the Covenant," 20.

100 See Fasce, La lode del medico, 49.

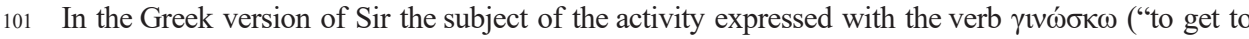
know," "to know") is almost exclusively a human being (see 1:6; 4:24; 6:27; 8:18; 11:28; 12:1,11; $16: 17 ; 18: 28 ; 23: 19 ; 24: 28 ; 26: 9 ; 34: 9 ; 36: 17 ; 37: 8 ; 46: 6,15$; the exceptions are Sir 23:20; 42:18, which mention God, who knows all). The objects of the knowledge expressed with the verb vary: these could be e.g. wisdom (see 1:6; 4:24; 6:27; 18:28; 24:28), another person or some aspect of their life (see 11:28; 12:1,11; 16:17; 26:9; 37:8; 46:6,15). It can also be God (see 23:19 and 36:17). It is only in Sir 38:5 that the object of cognition is i $\sigma \chi 0$ ("physical strength," "power," "might"). The noun most often signifies a man's physical strength - his robustness (see 3:13; 5:2; 9:2; 11:12; $16: 7 ; 17: 3 ; 19: 28 ; 31: 30 ; 38: 18 ; 41: 2 ; 43: 30 ; 46: 9$ ). It was used five times to denote power (see $28: 10$; 40:26; 44:6; 45:8,12). Twice, it indicates a man's capability of doing something (see 9:14 and 14:13).

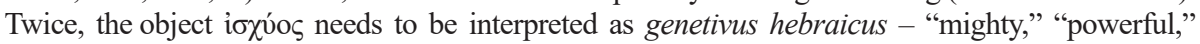
"strong" (see 6:29 and 34:16). Apart from 38:5, it is used only two times in the Greek text of Sir with reference to objects or things. 38:30 mentions the power of clay, and 39:28 the might of the wind.

102 See Piwowar, Sktadnia języka greckiego Nowego Testamentu, § 479 and $\S 482$.

103 See Piwowar, Składnia języka greckiego Nowego Testamentu, § 488.

104 See Fasce, La lode del medico, 44. 


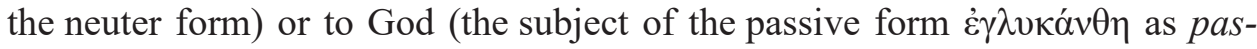
sivum theologicum; then it would be of the masculine form). In the former case, the healing power of wood would be evoked, while in the latter - of God. ${ }^{105}$ Even though the assumed subject of $38: 5 \mathrm{a}$ is God, the personal pronoun in the genitive in 38:5b needs to be applied to wood, as in the analyzed verse the sage emphasizes the fact that wood has healing properties. ${ }^{106}$ That God may heal or perform a miracle is a known and irrefutable truth, which Ben Sira did not need to prove. Attention in Sir 38:5 is drawn not to God but to the tool - the means through which water became potable. ${ }^{107}$ This interpretation is more in accord with the intention of the author, who wished to prove the healing properties of certain plants used to produce medicines.

It needs to be stressed that the main aim of the event described in Exod 15:25 is not to teach the Israelites about the healing power of natural substances, as is the case with Sir 38:5, but to call on the Israelites to obey God. The Deuteronomistic addition (Exod 15:25b-26) ${ }^{108}$ states that if they are to obey God, he will deliver them from various dangers. God himself is their doctor, that is the one who will give them prosperity and safety. ${ }^{109}$

Ben Sira used the Marah event as evidence for the healing properties of natural medicaments and as an argument for the sake of their use by those who believe in God. Since God himself told Moses ${ }^{110}$ to use wood to turn ("cure") bitter water into drinkable water, there are no reasons not to use medicaments offered by nature itself. They were created by God and have nothing to do with demonic forces or magic. ${ }^{111}$ The Hebrew text of Sir 38:5 corresponds to its translation into Greek. ${ }^{112}$

105 See Fasce, La lode del medico, 44-45; Noorda, "Illness and Sin, Forgiving and Healing," 219, n. 14; Vella, "Eclesiastico," 156.

106 See Snaith, Ecclesiasticus, 185.

107 Fasce (La lode del medico, 43) interprets Sir 38:5 in the same way, translating it as follows: "L'acqua non fu addolcita col legno, perché fosse conosciuta la sua proprietà?"

108 See B.S. Childs, Il libro dell'Esodo. Commentario critico-teologico (Casale Monferrato: Piemme 1995) 277-278; M. Noth, Esodo (Antico Testamento 5; Brescia: Paideia 1977) 159.

109 See Childs, Il libro dell'Esodo, 281; J.I. Durham, Exodus (WBC 3; Waco, TX: Word Books 1987) 213-214; Fasce, La lode del medico, 56-57; Lemański, Księga Wyjścia, 350-351; Lührmann, “Aber auch Arzt gib Raum (Sir 38,1-15)," 62; Noth, Esodo, 159-160; Propp, Exodus 1-18, 581-582; Zapff, "Sir 38,1-15 als Beispiel," 361.

110 Sulmasy ("The Covenant within the Covenant," 20) maintains that in his interpretation of the Marah event Ben Sira attributes to Moses the role of a doctor.

111 "Ben Sira è interessato alla peculiarità naturale dell'arbusto in quanto indicata direttamente da Dio, un donum di conoscenza ricevuto tramite Mosè, quindi una prova della dignità e della legittimità delle medicine naturali. Altre implicazioni dell'episodio, che senza dubbio non sfuggono e ne fondano il senso allegorico, non sono toccate" (Fasce, La lode del medico, 51).

112 "Was not water made sweet through wood so that each man could know its strenght?"). Manuscript B contains two notes on the margin of Sir 38:5. The first

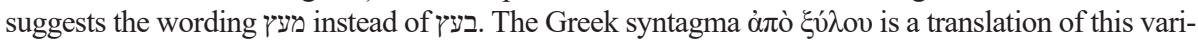




\subsection{The Origin and Aim of Medical Knowledge (Sir 38:6)}

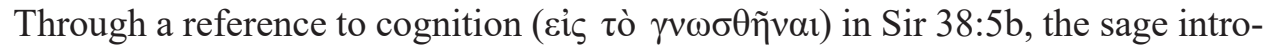
duces the subject of the central verse of the whole pericope of 38:4-8 - medical

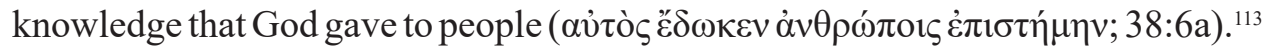

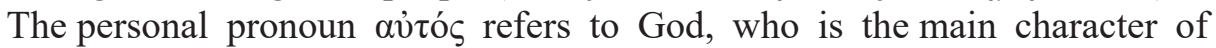

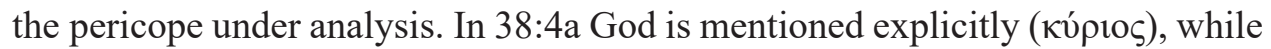

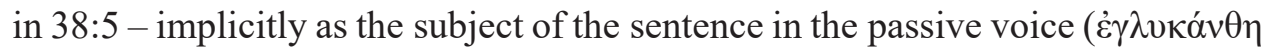
as passivum theologicum).

The verb $\delta$ í $\delta \mu$ ("to give," "to lend," "to grant") appears seventy-six times in the Greek version of Sir apart from 38:6a. In twenty seven cases the subject of the sentence in which the verb is used is God. ${ }^{114}$ God gives various gifts to all the people or to selected individuals. In the context of analyzing Sir 38:6a, the most important of these are: a desire for wisdom (see 6:37) or wisdom itself (see 43:33; cf. 45:26), power over everything on earth (see 17:2), cognitive capacities (see 17:6), and health, life and blessing (see 34:17). Ben Sira voices his belief that wisdom itself as well as everything that is necessary for its cognition/ attainment come from God and are God's gift to people. He thus subscribes to people's complete cognitive dependence on the Most High (cf. Sir 1:1). This is confirmed also by the reference in Sir 38:5 to an event through which God himself taught people about the natural healing properties of wood. It was thanks to God's activity that people could learn about the positive qualities of the plant pointed out to Moses. Sir 38:6a expresses this truth in an explicit way: "And it was he [God] that gave knowledge to human beings."

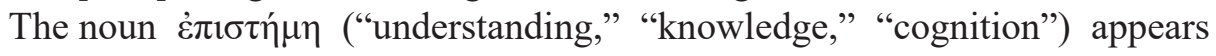
sixteen times in the Greek text of Sirach. God poured knowledge and cognition like a rain (see 1:19), he filled people with understanding (see 17:7,11) and made distinctions between them in the fullness of his knowledge (see 33:11). The Lord gave people knowledge together with the right to live (see 45:5). There are proverbs of knowledge in wisdom's treasuries (see 1:25). Wisdom elevates those who have attained it (see 10:30 and 38:3). The knowledge of evil is not wisdom (see 19:22). A wife's knowledge ensures prosperity for her husband (see 26:13), knowledge befits and old man (see 32:3) and characterizes a scribe. Ben Sire attained knowledge and contained it in his book (see 16:25; 50:27). He admon-

ant of the text placed on the margin. The second correction of B ${ }^{\text {text }}$ refers to the final ("his/its strength" with reference to God or wood; cf. Mopsik, La Sagesse de ben Sira, 219), corrected by B ${ }^{\text {marg }}$ into כוחם ("their strength" with reference to medicines in 38:4a). Cf. Morla, Los manuscritos hebreos de Ben Sira, 220, n. 1 and 2; Noorda, "Illness and Sin, Forgiving and Healing," 219, n. 14.

113 See Noorda, "Illness and Sin, Forgiving and Healing," 219.

114 See Sir 6:37; 15:17,20;17:2,6,24;23:4;26:3;34:17;36:14,15;37:21;43:33;44:23;45:5,7,17,20,21,26; $46: 9 ; 47: 5,11,22 ; 50: 23 ; 51: 22,30$. 
ishes his disciples/listeners to gain knowledge (see 16:24). In Ben Sira's point of view, knowledge is not merely erudition or an outcome of intellectual cognition. Since knowledge comes from God and is linked to wisdom, it has a clear religious and spiritual dimension. ${ }^{115}$ What is worthy of note, knowledge constitutes a great good for man, for thanks to it he can achieve a lot of positive things. The knowledge mentioned in Sir 38:6a should be applied to medicine (cf. 38:3a, which mentions the doctor's knowledge ${ }^{116}$ ) or, to be more precise, to a science of medicaments. The take on medicine in the stich analyzed here fits perfectly the understanding of knowledge conveyed in the whole Book of Sirach. It comes from God, God gave it to people, hence it is connected with God. It was given to people not only so that humanity had it for itself, but primarily so that God was worshipped for such a precious gift. This is clearly and univocally indicated by

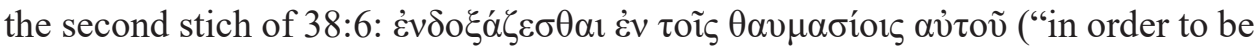
glorified due to his marvelous deeds").

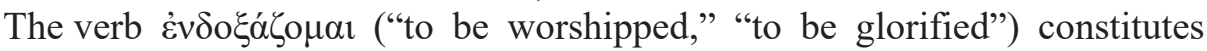
a hapax legomenon in the Greek version of Sir. It appears ten more times in other books of LXX. ${ }^{117}$ It refers only to God's majesty, both when God is glorified and when he metes out punishment. ${ }^{118}$ In Sir 38:6b the verb appears in the infinitive form of the present tense. Syntactically speaking, it may introduce a subordinate clause of purpose or result. ${ }^{119}$ In the first case, God's glorification would be a purpose - it was with his glorification in mind that he gave medical knowledge to people, while in the second case glorification would be a result of his having given this precious gift to people. Both interpretations are perfectly plausible in the context of Sir 38:6 and it is difficult to univocally determine which is correct. It seems that what is more important than the determination of the syntactic role of $\dot{\varepsilon} v \delta \circ \xi \dot{\alpha} \zeta \varepsilon \sigma \theta \alpha \mathrm{l}$ in Sir 38:6 is the activity itself rendered by the verb in the infinitive, that is glorification of God.

From the syntactic point of view, the second stich of Sir 38:6 poses two more difficulties. The first of these is the subject of the activity expressed through the verb in the passive voice $(\dot{\varepsilon} v \delta o \xi \dot{\alpha} \zeta \varepsilon \sigma \theta \alpha \mathrm{l})$. The second difficulty lies in

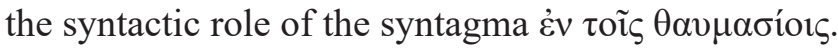

The subject of the activity expressed through the verb in the passive voice of the infinitive $\dot{\varepsilon} v \delta o \xi \dot{\alpha} \zeta \varepsilon \sigma \theta \alpha$ l may be people (the assumed subject; see 38:6a) or

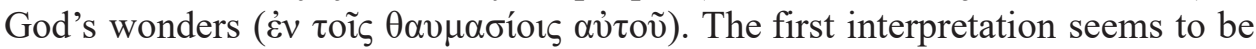

115 See Piwowar, "Respect for the Doctor (Sir 38:1-3)," 53-54; idem, "Uczony w Piśmie - ideał człowieka poszukującego mądrości (Syr 38,24; 39,1-11)," BibAn 6/4 (2016) 573-575.

116 See Fasce, La lode del medico, 45; Piwowar, "Respect for the Doctor (Sir 38:1-3)," 53-54.

117 See Exod 14:4,17,18; 33:16; 2 Kgs14:10; Ps 88:8; Ezek 28:22; 38:23; Hag 1:8.

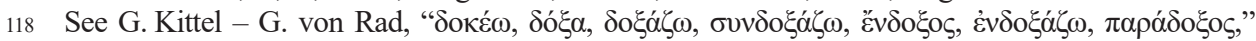
TDNT II, 254.

119 See Piwowar, Sktadnia języka greckiego Nowego Testamentu, § 479 and $\S 488$. 
supported primarily by the fact that knowledge was given precisely to people (see 38:6a). They naturally become the ones who worship God for this gift. From the syntactic point of view, the subject worshipping God may also be his marvel-

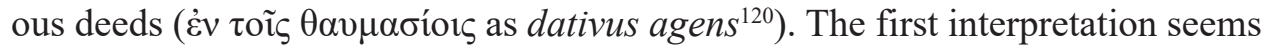
more logical as it fits the context better than the second one, which would pose certain problems with reference to people's relation with God: people would be merely passive recipients of a gift who do not in any way respond to the Divine Giver. Furthermore, God would be worshiped by his own deeds, which would constitute self-admiration of a kind.

The adjective $\theta \alpha v \mu \alpha \dot{\sigma} \sigma o \varsigma$ ("marvelous") appears eight more times in the Greek version of Sir apart from 38:6b. In five of them - as in the stich analyzed here - it is substantivized. God's wonders may not be tracked down (see 18:6) and even saints cannot describe them (see 42:17). A wealthy man without blame did wonders among his people (see 31:9). In his prayer for Israel's delivery, Ben Sira asks God to renew the signs and repeat the wonders (see 36:5). Elijah made a name for himself through his marvelous deeds (see 48:4). For God, nothing is a wonder, for he knows everybody and everything (see 39:20). It is only twice that the word analyzed here appears as an adjective qualifying the noun है $\rho \gamma \alpha$ (“deeds"). Animals created by God are described as amazing (see 43:25). Elisha performed marvelous deeds both during his lifetime and after death (see 48:14).

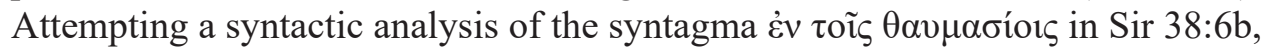
one needs to pay attention to $\operatorname{Sir} 48: 4 \mathrm{a}$, as the latter text contains the same expression ( $\dot{\varepsilon} v \theta \alpha v \mu \alpha \sigma i o 1 \varsigma)$, connected with the form of the verb $\delta o \xi \dot{\alpha} \zeta \omega$ in the passive voice ( $\dot{\varepsilon} \delta \mathrm{o} \xi \dot{\alpha} \sigma \theta \eta \varsigma$ ). In 48:4a this is passivum theologicum (God made the prophet famous), while in 38:6b the subject of $\dot{\varepsilon} v \delta o \xi \alpha \dot{\alpha} \xi \varepsilon \sigma \theta \alpha$ are people who received

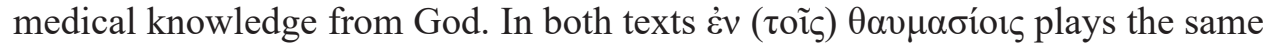
syntactic role. From the perspective of Greek syntax, the role can be defined as dativus instrumentalis ("through wonders," "with the help of wonders"), causae ("because of wonders"), loci ("in wonders") or as agens ("by wonders" - it was wonders who did the glorification), already presented and ruled out above. Out of the options presented above, its role as dativus causae seems the most appropriate interpretation. Both in the case of God (see 38:6b) and Elijah (see 48:4a) glorification/adoration happened as a result of the marvelous and extraordinary deeds they had performed.

The marvelous deeds that are the reason for God's glorification in 38:6b need to be related to medical knowledge and an ability to cure diseases with plants given to people upon the creation of the world. ${ }^{121}$ They can pertain as well to

120 See M.J. Harris, Prepositions and Theology in Greek New Testament. An Essential Reference Resource for Exegesis (Grand Rapids, MI: Zondervan 2012) 120.

121 See Adinolfi, "Il medico in Sir 38,1-15," 178; Noorda, "Illness and Sin, Forgiving and Healing," 219; Skehan - Di Lella, The Wisdom of Ben Sira, 442; Zapff, Jesus Sirach 25-51, 255. 
specific examples of curing a person thanks to therapy based on medicaments produced from plants. In 38:6 Ben Sira expresses - albeit indirectly - a traditional theological idea that God is the only Doctor. It was God who gave people knowledge about healing and it is God that the healing power of plants comes from. He also indicates the attitude that should be adopted by a person benefitting from these gifts: he should glorify God and worship him on account of all that God did for and gave to him.

The message of the Hebrew text of Sir 38:6 is similar to its Greek translation. The original text of Sir 38:6a in B ${ }^{\text {text }}$ reads as follows: ויתן לאנוש בינה (He gave people understanding"). ${ }^{122}$ It is in accord with its translation into Greek if we take into account the fact that the noun אנוש may have a collective meaning of "all the people," "mankind" (cf. Greek $\alpha v \theta \rho \omega ́ \pi \mathrm{or} \varsigma)^{123}$ and that the original meaning of the noun غं $\pi \iota \sigma \tau \dot{\mu} \mu \eta$ is "understanding," "cognition" (Hebrew בינה). ${ }^{124}$ It is only the second stich that evinces some differences between the original version and its translation. B Bext of Sir 38:6b contains the following words: להתפאר בגבורתו in order to manifest his glory / so that he manifested his glory on account of his mighty deeds / through his mighty deeds") ${ }^{125}$. B ${ }^{\text {marg }}$ suggests that the final word of the stich be read as בגבורתם ("on account of their mighty deeds / through their mighty deeds"). The singular form of the pronoun in $\mathrm{B}^{\text {text }}$ connects might to God, while the plural form of the pronoun in $\mathrm{B}^{\text {marg }}$ points to medicaments. " ${ }^{126} \mathrm{The} \mathrm{He}$ brew noun גבורה in the plural form (גבורת) may mean "mighty deeds," "wonders." The Hebrew version emphasizes the might of God $\left(\mathrm{B}^{\text {text }}\right)^{127}$ or medicines $\left(\mathrm{B}^{\text {marg }}\right)$, while the Greek text puts emphasis on the marvelousness and extraordinariness of God's actions. Both of these aspects can be easily reconciled in the theological understanding proposed by the Old Testament, according to which God performs great and mighty deeds that in people's eyes appear as miracles and extraordinary phenomena. Hence, there is no significant difference between the original version of Sir 38:6b and its translation into Greek. ${ }^{128}$

122 See Mopsik, La Sagesse de ben Sira, 219, n. 3.

123 See Askin, Scribal Culture in Ben Sira, 199; Morla, Los manuscritos hebreos de Ben Sira, 220, n. 4.

124 See R. Romizi, Greco antico. Vocabolario greco italiano etimologico e ragionato, 3 ed. (Bologna: Zanichelli 2007) 528.

125 The Hebrew text of Sir 38:6b poses the same syntactic problems as its Greek translation. The prepoב may indicate either a cause or a means (tool).

126 See Morla, Los manuscritos hebreos de Ben Sira, 220, n. 5. Cf. Zapff, Jesus Sirach 25-51, 255.

127 See Askin, Scribal Culture in Ben Sira, 199.

128 See Fasce, La lode del medico, 45; Mopsik, La Sagesse de ben Sira, 219, n. 4. 


\subsection{The Aim of Using Medicaments (Sir 38:7-8)}

In the last part of the analyzed pericope (Sir 38:4-8) the sage returns to medicaments, the subject matter of the first section (38:4-5). In this way, medicines form the frame for the structure of this literary unit (see the introduction to section 4). In the first two verses of the pericope, Ben Sira shows the origin of medicaments, thereby eradicating any fears concerning their use, while in 38:7-8 he focuses on the aim of their usage, that is healing (v. 7) and restoration of the order intended during the act of creation, an order which is violated and destroyed by pain and disease (v. 8).

The first part of the first stich (Sir 38:7a $\alpha$ ) presents the major aim of the production and deployment of medicines, namely the treatment of diseases and

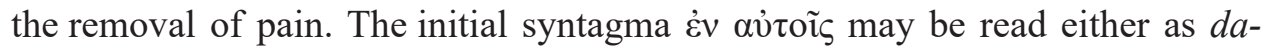
tivus instrumentalis ("through their help," "with their help," "thanks to them"), or as dativus causae ("on account of them"). The first interpretation seems more logical, as according to it medicines are a means (a tool) through which the doctor helps the sick one regain health and physical strength. The personal pronoun

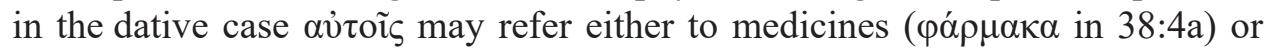

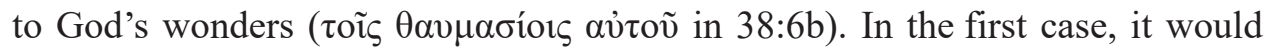
refer to the main theme of the pericope, while in the second it would indicate

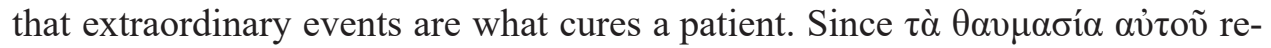
fers to the healing properties of plants created by God (see the interpretation of Sir 38:7b in section 4.2), for which reason they are used to produce medicaments, it may be assumed that wonders also indirectly refer to medicaments.

The verb $\theta \varepsilon \rho \alpha \pi \varepsilon v$ $\omega$ ("to be a servant," "to serve," "to cure," "to heal") appears only two more times in the Greek version of Sir apart from 38:7a . In 18:19 the sage calls on his disciple/listener to try to predict what is going to happen. Therefore, he should prepare before he speaks and take preventive care of himself before he gets sick ( $\pi \rho$ ò $\alpha \rho \rho \omega \sigma \tau i ́ \alpha \varsigma \theta \varepsilon \rho \alpha \pi \varepsilon v ́ o v$ - literally, "before an illness cure yourself"). In 35:16 in turn the word is used in its original meaning - "to serve." ${ }^{29}$ The first stich of the verse says that whoever serves ( $\left.\theta \varepsilon \rho \alpha \pi \varepsilon v ́ \omega v\right)$ God with goodwill will be accepted by him. In 38:7 - similarly to $18: 19 \mathrm{~b}$ - the verb refers to an activity that restores health to the sick one. Its assumed subject is God. He gave people medical knowledge (38:6a) and is glorified on account of healing properties of plants (38:6b). He cures ailments and suffering through medicaments $(38: 7 \mathrm{a} \alpha)$. In the initial part of the first stich of Sir 38:7a the sage clearly and univocally points to God as the one who heals. He heals through medicines that he created and contained in his various creations. The preceding context indicates especially plants (see 38:5). In this way, Ben Sira is on the one

129 See EDG I, 541; Romizi, Greco antico, 613-614. 
hand faithful to the Old Testament tradition of showing God as the only Doctor, while on the other hand he introduces a new element, claiming that God heals through medicaments. These are a means thanks to which the sick one regains health. It is yet another argument for using remedies in times of sickness, which refers to 38:4-5 and stems from the premises contained in these words.

The second aim of using medications during sickness is to quell pain: $\tilde{\eta} \rho \varepsilon v$

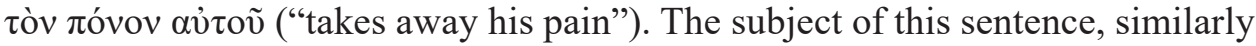

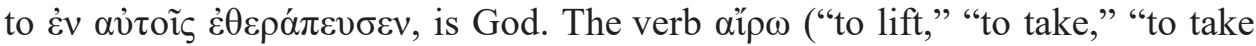
away," "to remove," "to destroy") appears only two more times in the Greek text of the Book of Sirach apart from the analyzed verse. In 13:2a the teacher of wisdom encourages his disciple not to take on a burden that surpasses

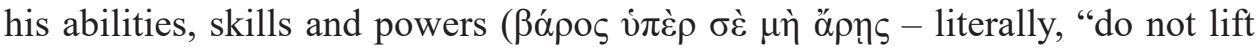
something too heavy for you"). In 20:11 the sage mentions people who do not give up despite humiliation and regain dignity ( $\kappa \varepsilon \varphi \alpha \lambda \eta ́ v$ - literally, "there is he who has raised his head from humiliation"). The subject of the sentence in both of these texts is a human being, while in Sir 38:7a $\beta$ it is God. It is God who removes pain ( ("hardship," "toil," "suffering," "pain," "anguish") appears five more times in the Greek translation of Sir. Twice it is used in a positive way: as an outcome of toil left as legacy to others (see 14:15) and as a fruit of hard work a wife is deprived of as a result of slander (see 28:15). People of a stubborn heart will have to bear hardship/drudgery (see 3:27). In 11:21 the sage encourages his disciple to believe in God and persevere in his toil. In the last two texts the word róvos expresses a certain inconvenience, a burden that makes one's life unpleasant and that causes problems. These preclude happiness and make one feel distressed and overwhelmed with the burden. Only in 31:20 is the meaning of the analyzed noun similar to suffering. It refers to sleeplessness caused by gluttony, the latter leading also to constipation and colic. Interestingly, the context preceding Sir 38:1-15 also mentions immoderation in eating and problems related to it. ${ }^{130}$ It may suggest that in 38:7a $\beta$ the sage had in mind pain and stomach troubles resultant from overeating. It is only an assumption, however, as the text of the analyzed stich does not mention it explicitly. Therefore, it should be assumed that

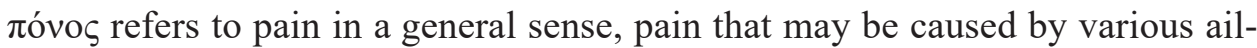
ments and diseases.

In Sir 38:7a $\beta$ the pain that God takes away from the person is rendered

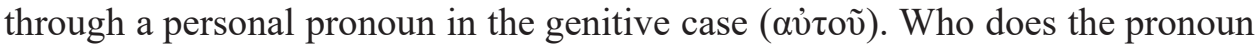
refer to and what syntactic role does it play? It may refer to God or to the person who suffers pain. It seems that the first interpretation is more plausible, as God is the subject of the activities expressed through $\dot{\varepsilon} \theta \varepsilon \rho \alpha ́ \pi \varepsilon v \sigma \varepsilon v$ and $\tilde{\eta} \rho \varepsilon v$. What

130 See Piwowar, "Respect for the Doctor (Sir 38:1-3)," 38. 
is more, Sir 38:4-8 does not mention a sick person directly, even though it presupposes his or her existence as it mentions medicines used to treat diseases. On this basis it may be assumed that the pronoun in question refers to God. What role is then ascribed to God with reference to pain mentioned in 38:7a $\beta$ ? In other

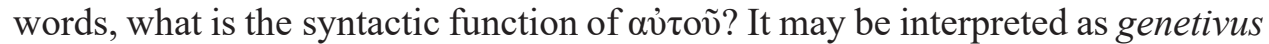
originis (pain comes from God), subiectivus ( óvos is a deverbal noun; ${ }^{131}$ pain that was caused by God), or causae (God is the cause of the sick one's pain). All of these interpretations of the pronoun fit the context of Sir 38:7 and, what may come as a surprise to a contemporary reader, the perception of causes of illness in the times of the Old Testament (it was believed that disease and suffering are a consequence of committed evil and constitute God's punishment in accord with the principle of retribution ${ }^{132}$ ). It is difficult to choose only one of these interpretations. The translator of the original text may have wished to generally point to the connection of illness and pain with God; according to the teachings of the Holy Scripture, these come from God. If this analysis is correct, the Greek text of Sir 38:7a expresses the view that God himself causes suffering and ailments to then cure them through medicaments. He would then be the source of both disease and healing. He would be the only one that human life fully and exclusively depends on.

Both verbal forms in Sir 38:7a appear in the affirmative form of the aorist. They do not refer to an activity performed once, though, but should be treated as aoristus gnomicus. ${ }^{133}$ They express God's constant activity, which is in a way a norm for his conduct.

The second stich of 38:7 refers to a person who prepares medicaments. It alludes also to medical knowledge that God gave to people (38:6a). The Greek noun $\mu \nu \rho \varepsilon \psi$ ó $\varsigma$ ("he who prepares aromatic ointments/perfumes," "perfume-mak-

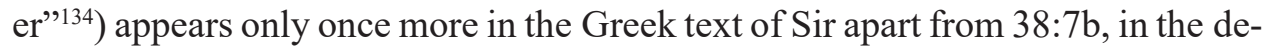
scription of Josiah in the Praise of the Fathers (see 49:1). His memory is like

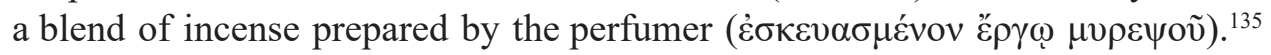
Such a meaning of the word is confirmed by other texts of LXX that make use of the word. ${ }^{136}$ It is worthy of note that perfume-makers performed an important liturgical service: they prepared incense (see Exod 30:35) and holy oil (see Exod 30:25; 38:25). 1 Chronicles 9:30 maintains that this was done by priests' sons, but the fruit of their work was not necessarily used in liturgy only. In all

131 See EDG II, 1172; Romizi, Greco antico, 1025.

132 See Piwowar, "Respect for the Doctor (Sir 38:1-3)," 32.

133 See Piwowar, Sktadnia języka greckiego Nowego Testamentu, § 336.

134 See Abramowiczówna (ed.), Stownik grecko-polski, III, 177; GELS, 470.

135 See R. Petraglio, Il libro che contamina le Mani. Ben Sirac rilegge il libro e la storia d'Israele (Theologia 4; Palermo: Edizionni Augustinus 1993) 332.

136 See Exod 30:25,35; 38:25; 1 Sam 8:13; 1 Chr 9:30; 2 Chr 16:14 and Song 3:6. 
likelihood, they also produced various types of perfumes and cosmetics. People termed $\mu \nu \rho \varepsilon \psi o i$ were thus engaged in the production of perfume of both liturgic and everyday use, also as medicines (for this reason the Greek word $\mu \nu \rho \varepsilon \psi o ́ s$ is translated by some as an apothecary). They used various plants in their work (see Exod 30:22-24,34). The context of Sir 38:7b makes it clear that the sage univocally connects the activity of $\mu \nu \rho \varepsilon \psi o$ of with the preparation of medicaments. The fruit of their work is termed $\mu \varepsilon i \tau \mu \alpha$ ("mixture/blend"137). This Greek noun is a hapax legomenon not only in the Greek version of the Book of Sirach but in the whole LXX. One may wonder why Ben Sira's grandson, speaking of medicines, did not use the word pápнакоv (see 38:4a). The Hebrew text reads here מרקחת ("blend of unguents"). Maybe both Ben Sira and his grandson wanted to emphasize the fact that the person who prepares those mixtures does more than produces medicaments; the scope of his activity is way broader and the substances he produces are used not only for medical purposes but also for esthetic ones. The use of the noun "medicament" would restrict the scope of the work of $\mu \nu \rho \varepsilon \psi$ ós, while the noun "mixture" more fully captures its meaning, doing justice to a broader scope of activity.

The Greek text of Sir 38:7b also mentions what the person preparing oint-

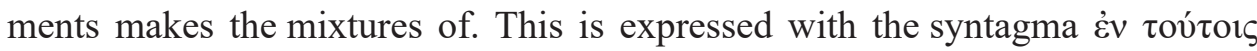
("with them"). The demonstrative pronoun in the dative refers to $\dot{\varepsilon} v$ av่ $\tau$ oĩ $\mathrm{s}$ in

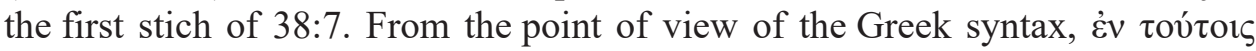
may be treated as dativus instrumentalis or causae. The first of these would point to plants of healing properties as a material out of which (through which, thanks to which) ointments are produced. The second, in turn, would clarify the reason behind his work: he prepares mixtures because some plants possess qualities used in medicine. The first interpretation better fits the context of Sir 38:7 and should be embraced.

The preparer of unguents makes use of the natural healing properties of certain plants in the preparation of medicaments that help cure diseases and ailments. His role is then akin to that of a doctor (see 38:1-3). He is a collaborator of God, the only Doctor. God gave him knowledge about healing plants, thanks to which he prepares medicaments used by doctors. Healing of an illness depends solely on God, however. This truth is expressed in a straightforward way in the last verse of the pericope studied here (especially the second stich of the verse).

The analysis of Sir 38:7 should incorporate one more important fact conveyed by the text. In ancient Egypt doctors did not only treat patients but also prepared medicines. Ben Sira, in contrast, seems to differentiate between a doctor (i $\alpha \tau \rho o ́ s$ ) and the preparer of medicaments ( $\mu \nu \rho \varepsilon \psi o ́ s)$. This may testify to the fact that two

137 See Abramowiczówna (ed.), Stownik grecko-polski, III, 150; Liddell - Scott, A Greek-English Lexicon, 1132; Montanari, Vocabolario della lingua greca, 1317; GELS, 447. 
independent professions were already distinguished, which would constitute a significant step in the development of medicine.

The Hebrew text of Sir 38:7a (בהם רופא יניח מכאוב - "by them the doctor takes away the pain") contains one important difference vis-à-vis its Greek translation. The doctor (רופא) is mentioned explicitly as the one who cures a person. The Greek text implicitly attributes this activity to God. The difference may stem from differing contexts from which the two texts originated. In his text, Ben Sira wished to encourage his contemporaries to make use of doctors' services (see Sir 38:1-3) and for this reason he pointed directly to the doctor as the one who cures illnesses. His grandson, living in Hellenized Alexandria, where doctors were commonly accessible and did not raise great controversies, may have wished to remind his compatriots that God is the only Doctor.

The Greek translation of the second stich of Sir 38:7 differs slightly from the original text (וכן רוקח עושה מרקחת - literally, "that is why the maker of perfume makes the mixture of perfume"138). The Greek version replaced the adverb

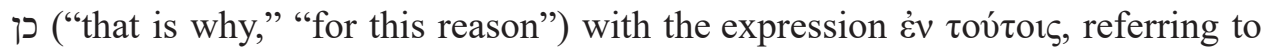
the material of which medicines are produced. The margin of Manuscript B proposes a very interesting wording: instead of ("he who prepares perfumes," or, alternatively, "apothecary"139) it reads קרח (participium Qal of the root "to have a shaved head"). The change proposed by B ${ }^{\text {marg }}$ may testify to the fact that medicine in Palestine developed due to Egyptian influences. Priests in Egypt shaved off their heads and engaged in medicine. The wording קרח seems to corroborate this assumption (which is not certain, though). ${ }^{140}$

In Sir 38:7 the sage indicates the aim of the use of medicine by those who are sick and suffering. In the final verse of the pericope analyzed here (38:8) he broadens his reflections and moves on from the sick to the whole creation, from the sickness and suffering of an individual to the harmony and order of the whole earth.

The first stich of Sir 38:8 begins with an emphatic negation referring to the future ov่ $\mu$ ๆे $\sigma v v \tau \varepsilon \lambda \varepsilon \sigma \theta \tilde{\eta}$ ("will never be finished"). This expression is used in Greek to express in the most decisive way a certainty that something will never happen or that the activity expressed in coniunctivus aoristi will never be real-

138 See Morla, Los manuscritos hebreos de Ben Sira, 220, n. 7.

139 See HALOT III, 1289.

140 The shaving off of one's head expressed with the root קרח was related to the mourning practices of pagan peoples (see Ezek 27:31; Jer 16:6), and for this reason the priests should not have their hair cut (see Lev 21:5). Cf. J.E. Hartley, Leviticus (WBC 4; Dallas, TX: Word Books 1992) 348; J. Milgrom, Leviticus 17 - 22. A New Translation with Introduction and Commentary (AB 3A; New York London - Toronto: Doubleday 2000) 1801-1803; M. Noth, Levitico (Antico Testamento 6; Brescia: Paideia 1989) 195; A. Tronina, Księga Kapłańska (NKB.ST 3; Częstochowa: Edycja Świętego Paweł 2006) 312. 
ized. ${ }^{141}$ The Greek version of the analyzed verse posits that God's works will

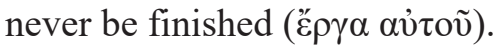

The verb $\sigma 0 v \tau \varepsilon \lambda \dot{\varepsilon} \omega$ ("to complete," "to finish," "to realize") appears in the Greek text of Sir seven more times apart from 38:8a. Its subject may be a human being (see 18:7; 24:28; 34:8 and 50:19) or God (see 23:20; 45:19). An analysis of Sir 38:8a needs to take into consideration the text of 23:20. According to the latter text, God had known everything even before he created it

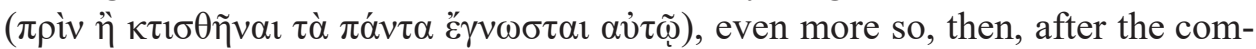

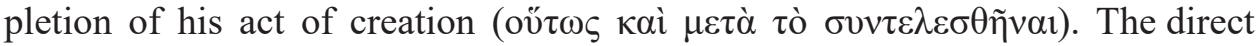

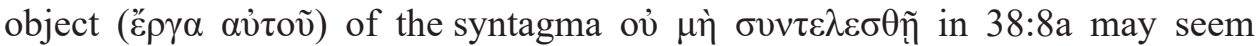
to suggest at first glance that the stich refers to creation. The expression "ै $\rho \gamma \alpha$

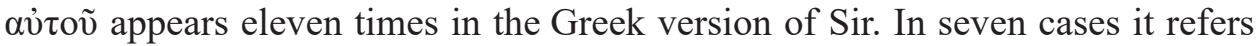
to God's works, ${ }^{142}$ while only in four - to human deeds. ${ }^{143}$ In Sir 38:8a the genitive case of the personal pronoun ( $\alpha$ vĩov) undoubtedly refers to God, for God is the main character of the whole pericope. God's works may signify creatures that he brought into being (see $1: 9 ; 16: 12,26,27 ; 42: 22$ ) or the actions that he has performed or is performing for the sake of people (see 11:4; 18:4). The context

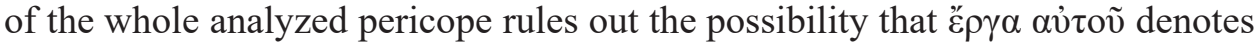
works created by God, for Sir 38:4-8 does not focus on the creative activity of God but on the healing that he performs with the use of medicaments. The works mentioned in Sir 38:8a need to be understood as God's actions undertaken for the sake of people. God's works are then primarily healing and alleviation of pain. The Greek text of Sir 38:8a expresses a steadfast conviction that God will continue his work of healing and will never stop working in this particular sphere of human life. If such an interpretation is correct, the Greek version of the analyzed text once more reminds the reader of the theological truth emphasized in the Old Testament that God is the only Doctor and only he can heal a person.

The second stich of 38:8 seems to indicate the aim of God's works and their outcome. They are geared towards the establishment and the keeping of peace in

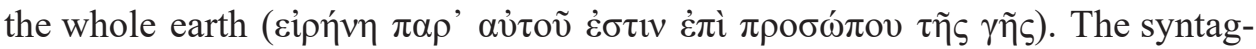
ma $\pi \alpha \rho$ ' $\alpha$ $\tau$ ¿ov clearly and univocally indicates who is the source of peace and

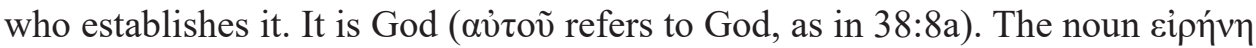
("peace," "harmony," "prosperity"144) appears ten more times in the Greek text of Sir. At times it is difficult to ascribe a precise meaning to it, as in many texts it may refer to peace understood both as harmony or absence of conflict (see Sir 13:18; 41:14; 45:24) as well as broadly understood prosperity (see Sir 26:2;

141 See Piwowar, Składnia języka greckiego Nowego Testamentu, § 387.

142 See Sir 1:9; $11: 14 ; 16: 26-27 ; 18: 4 ; 42: 22$ and $43: 28$.

143 See Sir 16:12,14; 17:19 and 48:14.

144 See GELS, 195. 
$44: 14 ; 47: 13,16 ; 50: 23) .{ }^{145}$ In Sir 1:18 the sage links peace with health - achieved thanks to healing ${ }^{146}$ or stemming from healing ${ }^{147}$ - which are both fruits of fear

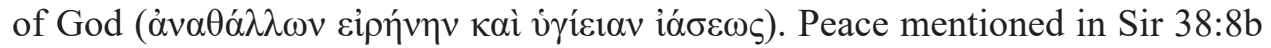
does not merely signify an absence of personal conflicts; it has a much broader meaning, frequently encountered in the Old Testament. ${ }^{148}$ In the context of heal-

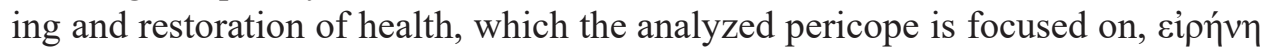
seems to refer to a person's health. Disease violated their peace, that is a harmonious and happy existence, and introduced chaos into their life. God created a healthy human being, thus illness is perceived as a violation of this state. God's healing activity comes down to the restoration to the sick one of the lost order: in other words, of strength and health. The peace mentioned in the Greek version of Sir 38:8b should be understood as restoration, that is as being cured of an illness and being given back health. In this way, Sir 38:8 would create a frame for Sir 38:4-8 as a literary unit (see the section on the delimitation of text). If this interpretation is correct, the second stich of 38:8 - like the first one - points to God as the only Doctor who by healing a person restores the order and harmony of human life created by him and disrupted by pain and suffering.

The original text of Sir 38:8 differs significantly, especially in its second stich, from its translation into Greek. In Manuscript B the text of the first stich is incomplete: לי[.][ן לא יש[..][ת מעשהו. Morla fills in the missing letters in the following way: למע לא ישבות מעשהו ("so that his works/work will not finish"). ${ }^{149}$ In a note on the margin the redactor of the manuscript suggests that the word $\Omega[.$.$] י be read$ as ישכח (imperfectum Qal of the root שכח - "to forget"). The reconstructed wording of $\mathrm{B}^{\text {text }}$ is more in accord with the Greek version than the change proposed by $\mathrm{B}^{\text {marg }}$ ("so as not to forget his work"). ${ }^{150}$ The Hebrew original of Sir 38:8a contains a clause of purpose, while its Greek version - an emphatic prohibition referring to the future. What is more, in the Hebrew text, the suffix of the pronoun in third person singular in the masculine case ("his") refers rather to a doctor (this is clear

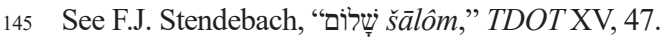

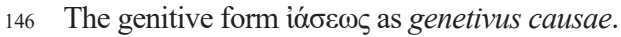

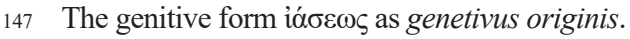

148 "Hebrajskie słowo šalôm pochodzi od rdzenia, który według powszechnego użycia oznacza: 'być nietkniętym,' 'być pełnym,' 'skończonym' [...] lub wyraża ideę przywrócenia pewnych rzeczy do ich pierwotnego stanu, do ich dawnej nieskazitelności [...], albo ideę złożenia ślubów (Ps 50,14). Tak więc 'pokój' w ujęciu biblijnym nie oznacza jedynie paktu, który pozwala wieść życie 'spokojne', nie oznacza też 'czasu pokoju' w przeciwstawieniu do 'czasu wojny' (Eccl 3,8; Rev 6,4). Pokój w Biblii - to dobrobyt codziennego istnienia, harmonia, w jakiej znajduje się człowiek w stosunku do całej przyrody, do Boga i do siebie samego; konsekwentnie - jest to błogosławieństwo, odpoczynek, chwała, bogactwo, zbawienie, życie" (X. Léon-Dufour, "Pokój," STB, 700-701). Cf. W. Fo-

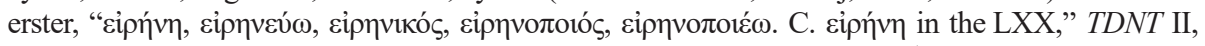
408; J.P. Healey, "Peace. Old Testament," ABD V, 206-207; Stendebach, "“ש̌ šālôm," 13-49.

149 See Morla, Los manuscritos hebreos de Ben Sira, 220, n. 8.

150 See Morla, Los manuscritos hebreos de Ben Sira, 220, n. 8 . 
from the context, see 38:7a), while in the Greek translation of these words $\alpha$ vovo refers to God. The difference between the singular form מעשהו and the plural

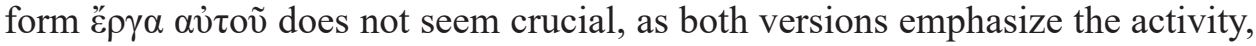
or to be more precise, its results: the Hebrew text shows them in a comprehensive way as a whole, while the Greek text mentions individual deeds.

A much more significant difference exists between the Hebrew and Greek version of Sir 38:8b. The original text mentions the efficacy or success (or, al-

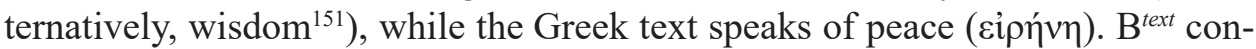
tains the following wording: ותושיה מבני אדם (literally, "nor efficacy among sons of man"). B Barg instead of מפני ארצו proposes ("from the surface of his

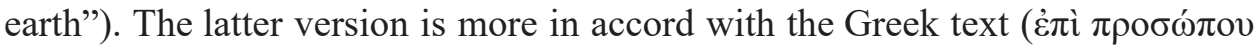
$\tau \tilde{\eta} \varsigma \gamma \tilde{\eta} \varsigma$ ) than $\mathrm{B}^{\text {text }}{ }^{152}$ for which reason Peters considers it to be derivative. ${ }^{153}$ It has to be noted too that the second stich lacks a verbal form, which makes it dependent on the first part of 38:8. According to the original version, neither the doctor's activity nor his efficacy will ever finish. The Greek version of the second stich, by contrast, contains the form غ̇ $\sigma \tau v$, thus claiming that peace on earth stems from God.

Comparing the Hebrew text of Sir 38:8 with its Greek counterpart, it needs to be concluded that the former focuses on the work of the doctor and the preparer of ointments, ${ }^{154}$ while the second emphasizes God's direct activity.

\section{Conclusion}

In his reflection on medications that were of use in his times (Sir 38:4-8), Ben Sira encourages his listeners to make use of them in times of sickness to relieve pain. The reservations of contemporary Jews with regard to using medicaments were caused by the fact that medicine at that time resorted to magic both in the process of treatment and in preparation of remedies. Pious Jews were reluctant to use them since sorcery was forbidden by the Law as something defying faith in God. Ben Sira made an attempt to change the believers' perspective on medicines. First, he pointed out the source of the healing properties of remedies

151 See DBHE, 796; HALOT IV, 1713-1715.

152 See Morla, Los manuscritos hebreos de Ben Sira, 221, n. 1.

153 See Peters, Der jüngst wiederaufgefundene hebräische Text, 157; idem, Das Buch Jesus Sirach oder Ecclesiasticus, 312.

154 “Grâce au médecin et au pharmacien, l'œuvre divine ne cesse pas de réaliser ce pour quoi elle avait été faite. L'un comme l'autre prolongent l'œuvre de Dieu en la rendant opérante à travers les mixtures qu'ils préparent" (Mopsik, La Sagesse de ben Sira, 220, n. 1). Cf. Smend, Die Weisheit des Jesus Sirach erklärt, 340. 
(Sir 38:4-5). To persuade his listeners to share his point of view, he referred to the act of creation and to the events that occurred in Marah (Exod 15:23-25). On the basis of these examples, he proved that medicaments come from God and are thus good and should be used. Their production and application aims not only to restore health to the sick ones (Sir 38:7) but also to restore the order and harmony of the world, violated by pain and suffering. In Ben Sira's point of view, medicine and medicaments are part of God's creation, or even a continuation of God's act of creation for the sake of people. Doctors and medicaments are tools in God's hand through which the sick ones regain health. The sage states clearly that medical knowledge comes from God. He gave it to people to restore to the created world the order disturbed by illness. People should worship God for this gift and for the healing activity that he performs through doctors and medicines they prescribe to their patients.

Open to what is good and beneficial in other cultures, Ben Sira positively assesses the use of medicines. Through the connection between medicines and God, he links contemporary medicine with Israel's faith, according to which God is the only doctor. In Ben Sira's perception of healing, it is God who cures suffering and pain, but he does so through medicaments produced by people thanks to the knowledge God passed on to them.

It needs pointing out that the original version of Sir 38:4-8 emphasizes the role of a human doctor in the process of healing, while the Greek translation of the text concentrates more on God as the one that healing comes from. Without a doubt, the difference in focus discernible between the two versions is caused by a different location in which the texts were produced (Palestine and Hellenized Alexandria, respectively), or, to be more precise, by a different attitude of the texts' addressees to medicine and medications.

\section{Bibliography}

Abramowiczówna, Z. (ed.), Słownik grecko-polski (Warszawa: Państwowe Wydawnictwo Naukowe 1958-1965) IIV.

Adinolfi, M., "Il medico in Sir 38,1-15," Antonianum 62 (1987) 172-183.

Allan, N., "The Physician in Ancient Israel: His Status and Function," Medical History 45 (2001) 377-394.

Alonso Schökel, L., Diccionario bíblico hebreo-español, 2 ed. (Madrid: Trotta 1999) (= DBHE)

Alonso Schökel, L., Proverbios y Eclesiástico (Los Libros Sagrados 8/1; Madrid: Cristiandad 1968).

Askin, L.A., Scribal Culture in Ben Sira (Sir 38:1-15; 41:1-15; 43:11-19; 44-50) (doctoral diss.,

Queen's College, Cambridge University 2016) https://www.repository.cam.ac.uk/handle/1810/ 255388 [access: 01.03.2020].

Barbiero, G., Cantico dei cantici (I Libri Biblici. Primo Testamento 24; Milano: Paoline 2004). 
Beeks, R. - van Beck, L., Etymological Dictionary of Greek (Leiden Indo-European Etymological Dictionary Series 10; Leiden - Boston: Brill 2010) III (=EDG).

Beentjes, P.C., The Book of Ben Sira in Hebrew. A Text Edition of all Extant Hebrew Manuscripts and a Synopsis of all Parallel Hebrew Ben Sira Texts (Supplements to Vetus Testamentum 68; Leiden - New York - Köln: Brill 1997).

Blass, F. - Debrunner, A., Grammatica del Greco del Nuovo Testamento, 2 ed. (Introduzione alla Studio della Bibbia. Sumplementi 2; Brescia: Paideia 1997).

Boadt, L., Reading the Old Testament. An Introduction (New York: Paulist Press 1984).

Boccaccio, P. - Berardi G., Ecclesiasticus. Textus hebraeus secundum fragmenta reperta (Roma: PIB 1986).

The Book of Ben Sira. Text, Concordance and an Analysis of the Vocabulary (The Historical Dictionary of the Hebrew Language; Jerusalem: The Academy of the Hebrew Language and the Shrine of the Book 1973).

Brown, M.L., "רָָָָ rāpā'," Theological Dictionary of the Old Testament (eds. G.J. Botterweck H. Ringgren - H.-J. Fabry) (Grand Rapids, MI - Cambridge: Eerdmans 2004) XIII, 593-602.

Childs, B.S., Il libro dell'Esodo. Commentario critico-teologico (Casale Monferrato: Piemme 1995). Chrostowski, W., "Lekarz i jego posługa w świetle Biblii," Collectanea Theologica 71/3 (2001) 51-67.

Clines, D.J.A. (ed.), The Dictionary of Classical Hebrew (Sheffield: Sheffield Phoenix Press 1994-2016) IIX (= DHC).

Corley, J., Sirach (New Collegeville Bible Commentary 21; Collegeville, MN: Liturgical Press 2013). Cranz, I., "Advice for a Successful Doctor's Visit: King Asa Meets Ben Sira," The Catholic Biblical Quarterly 80/2 (2018) 231-246.

Crenshaw, J.L., "The Book of Sirach. Introduction, Commentary, and Reflection," The New Interpreter's Bible (ed. L.E. Keck) (Nashville, TN: Abingdon Press 1997) V, 601-867.

Duesberg, H., "Le médecin, un sage (Ecclésiastique 38,1-15)," Bible et vie chrétienne 38 (1961) 43-48.

Durham, J.I., Exodus (Word Biblical Commentary 3; Waco, TX: Word Books 1987).

Exum, J.C., Song of Songs. A Commentary (The Old Testament Library; Louisville, KY: Westminster John Knox 2005).

Fasce, S., La lode del medico nel libro biblico del Siracide (Genova: ECIG 2009).

Flawiusz, J., Wojna żydowska (Warszawa: Rytm 2016).

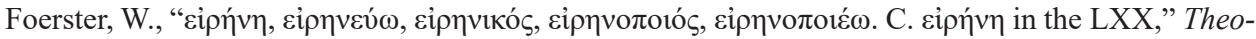
logical Dictionary of the New Testament (ed. G. Kittel) (Grand Rapids, MI: Eerdmans 1995) II, 406-408.

Gaiser, F.J., “"The Sensible Will Not Despise Him': Healing Medicine, Human Wisdom and God (Sirach 38:1-15)," Healing in the Bible. Theological Insight for Christian Ministry (ed. F.J. Gaiser) (Grand Rapids, MI: Baker 2010) 117-131.

Gaiser, F.J., The Song of Songs. A Continental Commentary (Minneapolis, MN: Fortress 1994).

Garrett, D. - House, P.R., Song of Songs/Lamentations (Word Biblical Commentary 23B; Nashville, TN: Nelson 2004).

Giblet, J. - Grelot, P., "Choroba-uleczenie," Stownik teologii biblijnej, 3 ed. (ed. X. Léon-Dufour) (Poznań: Pallottinum 1990) 121-125.

Harris, M.J., Prepositions and Theology in Greek New Testament. An Essential Reference Resource for Exegesis (Grand Rapids, MI: Zondervan 2012).

Hartley, J.E., Leviticus (Word Biblical Commentary 4; Dallas, TX: Word Books 1992). 
Healey, J.P., "Peace. Old Testament," The Anchor Bible Dictionary (ed. D.N. Freedman) (New York - London - Toronto: Doubleday 1992) V, 206-207.

Jacob, I. - Jacob W., "Flora," The Anchor Bible Dictionary (ed. D.N. Freedman) (New York - London - Toronto: Doubleday 1992) II, 803-817.

Jurewicz, O. (ed.), Stownik grecko-polski (Warszawa: Wydawnictwo Szkolne PWN 2000-2001) III.

Kam-Yau Chan, A. - Song, T.B. - Brown, M.L., "רפא," New International Dictionary of Old Testament Theology and Exegesis (ed. W.A. VanGemeren) (Carlise: Paternoster 1997) III, 1162-1173.

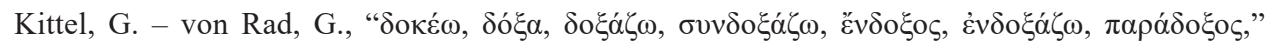
Theological Dictionary of the New Testament (ed. G. Kittel) (Grand Rapids, MI: Eerdmans 1995) II, 232-255 (= TDNT).

Koehler, L. - Baumgartner, W. - Stamm, J.J. (eds.), The Hebrew and Aramaic Lexicon of the Old Testament (Leiden - New York - Köln: Brilll 1994-2000) IV (= HALOT).

Kraus, W. - Karrer, M. (ed.), Septuaginta Deutsch. Das griechische Alte Testament in deutscher Übersetzung (Stuttgart: Deutsche Bibelgesellschaft 2009).

Grecko-polski Stary Testament. Księgi greckie. Przekład interlinearny z kodami gramatycznymi i indeksem form podstawowych (trans. M. Wojciechowski) (Prymasowska Seria Biblijna; Warszawa: Vocatio 2008).

Langkammer, H., Księga Pieśni nad pieśniami (Pismo Święte Starego Testamentu 8/4; Poznań: Pallottinum 2016).

Lemański, J., Księga Wyjścia (Nowy Komentarz Biblijny. Stary Testament 2; Częstochowa: Edycja Świętego Pawła 2009).

Léon-Dufour, X., “Pokój,” Stownik teologii biblijnej, 3 ed. (ed. X. Léon-Dufour) (Poznań: Pallottinum 1990) 700-705.

Lévi, I., The Hebrew Text of the Book of Ecclesiasticus (Semitic Study Series; Leiden: Brill 1904).

Liddell, H.G. - Scott, R., A Greek-English Lexicon, 10 ed. (Oxford: Clarendon 1996).

Longman III, T., Song of Songs (The New International Commentary on the Old Testament; Grand Rapids, MI - Cambridge: Eerdmans 2001).

Lührmann, D., “Aber auch Arzt gib Raum (Sir 38,1-15)," Wort und Dienst 15 (1979) 55-78.

Marböck, J., Weisheit im Wandel. Untersuchungen zur Weisheitstheologie bei Ben Sira (BZAW 272; Berlin - New York: de Gruyter 1999).

Mazzinghi, L., “«Poi fa' posto al Medico, perché ti è necessario» (Sir 38,1-15),” Parola, Sprito e Vita 40 (1999) 65-74.

Middendorp, T., Die Stellung Jesu Ben Siras zwischen Judentum und Hellenismus (Leiden: Brill 1973).

Milgrom, J., Leviticus 17 - 22. A New Translation with Introduction and Commentary (The Anchor Bible 3A; New York - London - Toronto: Doubleday 2000).

Minissale, A., Siracide (Ecclesiastico), 3 ed. (Nuovissima Versione della Bibbia 23; Cinisello Balsamo: San Paolo 2002).

Minissale, A., Siracide. Le radici nella tradizione (Leggere Oggi la Bibbia 1/17; Brescia: Queriniana 1988).

Montanari, F., Vocabolario della lingua greca, 2 ed. (Torino: Loescher Editore, 2004).

Mopsik, C., La Sagesse de ben Sira (Les Dix Paroles; Lagrasse: Verdier 2003).

Morla, V., Los manuscritos hebreos de Ben Sira. Traducción y notas (Asociación Bíblica Española 59; Estella: Editorial Verbo Divino 2012). 
Morla Asensio, V., Eclesiástico (El Mensaje del Antiguo Testamento 20; Salamanca: Sigueme 1992).

Muraoka, T., A Greek-English Lexicon of the Septuagint (Louvain - Paris - Walpole, MA: Peeters 2009) $(=$ GELS).

Muraoka, T., A Greek $\approx$ Hebrew / Aramaic Two-Way Index to the Septuagint (Louvain - Paris - Walpole, MA: Peters 2010).

Nelis, J.T., "Sir 38,15," Von Kanaan bis Kerala (FS J.P.M. van der Ploeg) (ed. W.C. Delsman J.T. Nelis - H.R.T.M. Peters) (Alter Orient und Altes Testament 211; Kevelaer - New York: Butzon \& Becker Kevelaer 1982) 173-184.

Noorda, S., "Illness and Sin, Forgiving and Healing: The Connection of Medical Treatment and Religious Beliefs in Ben Sira 38,1-15," Studies in Hellenistic Religions (ed. M. Vermaseren) (Études Préliminaires aux Religions Orientales dans L'Empire Romain 78; Leiden: Brill 1979) 215-224.

Noth, M., Esodo (Antico Testamento 5; Brescia: Paideia 1977).

Noth, M., Levitico (Antico Testamento 6; Brescia: Paideia 1989).

Packer, J.I. - Tenney, M.C. (ed.), Stownik tta Biblii (Prymasowska Seria Biblijna; Warszawa: Vocatio 2007).

Palmisano, M.C., Siracide. Introduzione, traduzione e commento (Nuova Versione della Bibbia dai Testi Antichi 34; Cinisello Balsamo: San Paolo 2016).

Pawlaczyk, B., "Kazuistyka medyczna,” Biblia a medycyna (ed. B. Pawlaczyk) (Poznań: Księgarnia Świętego Wojciecha 2007) 33-252.

Peters, N., Das Buch Jesus Sirach oder Ecclesiasticus (Exegetisches Handbuch zum Alten Testament 25; Münster: Aschendorff 1913).

Peters, N., Der jüngst wiederaufgefundene hebräische Text des Buches Ecclesiasticus (Freiburg im Breisgau: Herder 1902).

Petraglio, R., Il libro che contamina le Mani. Ben Sirac rilegge il libro e la storia d'Israele (Theologia 4; Palermo: Edizionni Augustinus 1993).

Pick, J., W świecie Biblii. Flora (Pelplin: Bernardinum 1998).

Pietersma, A. - Wright, B.G. (ed.), A New English Translation of the Septuagint. And the Other Greek Translations Traditionally Included under that Title (New York - Oxford: Oxford University Press 2007).

Piwowar, A., Sktadnia języka greckiego Nowego Testamentu, 2 ed. (Materiały Pomocnicze do Wykładów z Biblistyki 13; Lublin: Wydawnictwo KUL 2017).

Piwowar, A., "Respect for the Doctor (Sir 38:1-3)," Biblical Annals 10/1 (2020) 31-62.

Piwowar, A., "Uczony w Piśmie - ideał człowieka poszukującego mądrości (Syr 38,24; 39,1-11)," Biblical Annals 6/4 (2016) 527-600.

Piwowar, A., "Wierność w czasie próby (Syr 2,1-6)," Verbum Vitae 11 (2007) 99-126.

Piwowar, A., "Zdobycie mądrości według Syracha (Syr 6,18-37). Część I: Przyjęcie wychowania prowadzi do osiągnięcia mądrości (Syr 6,18-22)," Biblical Annals 5/1 (2015) 111-135.

Piwowar, A., "Zdobycie mądrości według Syracha (Syr 6,18-37). Część II: Poddanie się mądrości i jego skutki (Syr 6,23-31)," Biblical Annals 5/2 (2015) 319-349.

Pope, M.H., Song of Songs. A New Translation with Introduction and Commentary (The Anchor Bible 7C; New York - London - Toronto: Doubleday 1977).

Propp, W.H.C., Exodus 1-18 A New Translation with Introduction and Commentary (The Anchor Bible 2; New York - London - Toronto: Doubleday 1999). 
Pudełko, J.J., Wierny przyjaciel lekarstwem życia (Syr 6,16). Koncepcja przyjaźni w Księdze Syracydesa (Rozprawy i Studia Biblijne 28; Warszawa: Vocatio 2007).

Rahlfs, A. (ed.), Septuaginta. Id est Vetus Testamentum graece iuxta LXX interpretes (Stuttgart: Deutsche Bibelgesellschaft 1979) III.

Ravasi, G., "Malattia, Guarigione e medici nell'Antico Testamento," Parola, Sprito e Vita 40 (1999) $11-22$.

Ravasi, G., Il cantico dei cantici. Commento e attualizzazione (Testi e Commenti; Bologna: EDB 1992).

Romizi, R., Greco antico. Vocabolario greco italiano etimologico e ragionato, 3 ed. (Bologna: Zanichelli 2007).

Sauer, G., Jesus Sirach/Ben Sira (Das Alte Testament Deutsch. Apokryphen 1; Göttingen: Vandenhoeck \& Ruprecht 2000).

Schrader, L., "Beruf, Arbeit und Muße als Sinnerfüllung bei Jesus Sirach," Der Einzelne und seine Gemeinschaft bei Ben Sira (ed. R. Egger-Wenzel - I. Krammer) (BZAW 270; Berlin - New York: de Gruyter 1998) 117-149.

Septuaginta czyli Biblia Starego Testamentu wraz z księgami deuterokanonicznymi i apokryfami (trans. R. Popowski) (Prymasowska Seria Biblijna; Warszawa: Vocatio 2013).

Skehan, P.W. - Di Lella, A.A., The Wisdom of Ben Sira (The Anchor Bible 39; New York - London Toronto: Doubleday 1987).

Smend, R., Die Weisheit des Jesus Sirach erklärt (Berlin: Reimer 1906).

Smend, R., Die Weisheit des Jesus Sirach hebräisch und deutsch (Berlin: Reimer 1906).

Snaith, J.G., Ecclesiasticus or The Wisdom of Jesus Son of Sirach (The Cambridge Bible Commentary; Cambridge: Cambridge University Press 1974).

Stabryła, W.M., “Najlepszego nawet lekarza czeka Gehenna'. Lekarz w starożytnym Izraelu,” Ateneum Kapłańskie 160/1 (2013) 7-13.

Stabryła, W.M., "Zdrowie i choroba w starożytnym Izraelu," Więcej szczęścia jest w dawaniu aniżeli w braniu. Księga Pamiątkowa dla Księdza Profesora Waldemara Chrostowskiego w 60. rocznice urodzin (ed. B. Strzałkowska) (Ad Multos Annos; Warszawa: Adam 2011) III, 1313-1334.

Stadelmann, H., Ben Sira als Schriftgelehrter. Eine Untersuchung zum Berufsbild des vor-makkabäischen Sōfêr unter Berücksichtigung seines Verhältnisses zu Priester-, Propheten- und Weisheitslehrertum (WUNT 2/6; Tübingen: Mohr [Paul Siebeck] 1980).

Stendebach F.J., "שָׁ šālom," Theological Dictionary of the Old Testament (ed. G.J. Botterweck H. Ringgren - H.-J. Fabry) (Grand Rapids, MI - Cambridge: Eerdmans 2006) XV, 13-49.

Stöger, A., "Der Arzt nach Jesus Sirach (38,1-15)," Arzt und Christ 11/1 (1965) 3-11.

Sulmasy, D.P., "The Covenant within the Covenant: Doctors and Patients in Sir 38:1-15," Linacre Quarterly 55 (1988) 14-24.

Szczepanowicz, B., Rośliny biblijne. Ziemia Święta (Kraków: Petrus 2014).

Testa, E., "Le malattie e il medico secondo la Bibbia," Rivista Biblica 43 (1995) 253-267.

Tronina, A., Księga Kaptańska (Nowy Komentarz Biblijny. Stary Testament 3; Częstochowa: Edycja Świętego Pawła 2006).

Turkiel, J., "Septuaginta o lekarzu," Nauki humanistyczne i sozologia. Księa jubileuszowa dedykowana Księdzu Profesorowi zwyczajnemu doktorowi habilitowanemu Józefowi M. Dotędze (ed. J.W. Czartoszewski) (Warszawa: Wydawnictwo UKSW 2010) 563-570.

Yastrow, M. (ed.), A Dictionary of the Targumim, the Talmud Babli and Yerushalmi, and the Midrashic Literature with an Index of Scriptural Quotations (New York: The Judaica Press 1996) III. 
Vella, J., "Eclesiastico," La Sagrada Escritura. Texto y comentario. Antiguo Testamento. V. Eclesiástico, Isaía, Jeremías, Ezequiel (ed. A.T. Fernández) (Madrid: Católica 1970) 3-218.

Zakrzewska, M., "Choroba - zło dotykające człowieka," Biblia a medycyna (ed. B. Pawlaczyk) (Poznań: Księgarnia Świętego Wojciecha 2007) 15-27.

Zapff, B.M., Jesus Sirach 25 - 51 (Die Neue Echter Bibel. Altes Testament; Würzburg: Echter 2010). Zapff, B.M., "Sir 38,1-15 als Beispiel der Verknüpfung von Tradition und Innovation bei Jesus Sirach," Biblica 92 (2011) 347-367.

Ziegler, J., Sapientia Iesu Filii Sirach, 2 ed. (Septuaginta. Vetus Testamentum Graecum Auctoritate Academiae Scientiarum Gotteingensis editum 12/2; Göttingen: Vandenhoeck\&Ruprecht 1980). http://bensira.org/navigator.php?Manuscript=B\&PageNum=27 [access: 30.09 .2018 ]. 
